\title{
Thermodynamic Stability of Mg-based Ternary Long-Period Stacking Ordered Structures
}

\author{
James E. Saal*, C. Wolverton \\ Department of Materials Science and Engineering, \\ Northwestern University, Evanston, IL 60201, USA
}

\begin{abstract}
$\mathrm{Mg}$ alloys containing long-period stacking ordered (LPSO) structures exhibit remarkably high tensile yield strength and ductility. They have been found in a variety of ternary $\mathrm{Mg}$ systems of the general form $\mathrm{Mg}-\mathrm{X}^{\mathrm{L}}-\mathrm{X}^{\mathrm{S}}$, where $\mathrm{X}^{\mathrm{L}}$ and $\mathrm{X}^{\mathrm{S}}$ are elements larger and smaller than $\mathrm{Mg}$, respectively. In this work, we examine the thermodynamic stability of these LPSO precipitates with density functional theory, using a newly proposed structure model based on the inclusion of a $\mathrm{Mg}$ interstitial atom. We predict the stabilities for $14 \mathrm{H}$ and 18R LPSO structures for many $\mathrm{Mg}-\mathrm{X}^{\mathrm{L}}-\mathrm{X}^{\mathrm{L}}$ ternary systems: 85 systems consisting of $\mathrm{X}^{\mathrm{L}}=$ rare earths $(\mathrm{RE})$ $\mathrm{Sc}, \mathrm{Y}, \mathrm{La}-\mathrm{Lu}$ and $\mathrm{X}^{\mathrm{S}}=\mathrm{Zn}, \mathrm{Al}, \mathrm{Cu}, \mathrm{Co}, \mathrm{Ni}$. We predict thermodynamically stable LPSO phases in all systems where LPSO structures are observed. In addition, we predict several stable LPSO structures in new, as-yet-unobserved Mg-RE$\mathrm{X}^{\mathrm{S}}$ systems. Many non-RE $\mathrm{X}^{\mathrm{L}}$ elements are also explored on the basis of size mismatch between $\mathrm{Mg}$ and $\mathrm{X}^{\mathrm{L}}$, including $\mathrm{Tl}, \mathrm{Sb}, \mathrm{Pb}, \mathrm{Na}, \mathrm{Te}, \mathrm{Bi}, \mathrm{Pa}, \mathrm{Ca}, \mathrm{Th}, \mathrm{K}, \mathrm{Sr}-$ an additional 55 ternary systems. $\mathrm{X}^{\mathrm{L}}=\mathrm{Ca}, \mathrm{Sr}$, and $\mathrm{Th}$ are predicted to be most promising to form stable LPSO phases, particularly with $\mathrm{X}^{\mathrm{S}}=\mathrm{Zn}$. Lastly, several previously observed trends amongst known $\mathrm{X}^{\mathrm{L}}$ elements are examined. We find that favorable mixing energy between $\mathrm{Mg}$ and $\mathrm{X}^{\mathrm{L}}$ on the FCC lattice and the size mismatch together serve as excellent criteria determining $\mathrm{X}^{\mathrm{L}}$ LPSO formation.
\end{abstract}

\footnotetext{
* Corresponding author

Email address: j-saal@northwestern.edu (James E. Saal)
}

Preprint submitted to Acta Materialia

August 21, 2018 
Keywords: magnesium alloys, LPSO, phase stability, density functional theory, phase diagram

\section{Introduction}

Mg-based alloys are often considered potential lightweight structural alloys for transportation applications in efforts to improve efficiency. However, poor mechanical strength and ductility have long been impediments to wide industrial use of Mg. In 2001, Kawamura et al. reported a Mg alloy with a nominal composition of $\mathrm{Mg}_{97} \mathrm{Zn}_{1} \mathrm{Y}_{1}$ exhibiting a remarkably high tensile yield strength of $610 \mathrm{MPa}$ at $16 \%$ elongation[1]. This strength is coupled with the appearance of a novel ternary precipitate exhibiting order with long periods along the c-axis of the HCP Mg matrix[2]. Referred to as long period stacking ordered (LPSO) structures, these precipitates, and their resulting high strength, have since been observed in a variety of ternary Mg systems[3-13]. However, LPSO systems typically contain at least 1 at.\% rare earth (RE) elements, making such alloys prohibitively expensive for high-volume industrial applications.

LPSO structures have been reported in several $\mathrm{Mg}-\mathrm{X}^{\mathrm{L}}-\mathrm{X}^{\mathrm{S}}$ ternary systems, consisting of $\mathrm{Mg}$, an alloying element larger than $\mathrm{Mg}\left(\mathrm{X}^{\mathrm{L}}\right)$, and an alloying element smaller than $\mathrm{Mg}\left(\mathrm{X}^{\mathrm{S}}\right)$. Currently, the following alloying elements have been reported to form LPSO structures: $X^{\mathrm{L}}=\mathrm{Y}, \mathrm{Gd}, \mathrm{Tb}, \mathrm{Dy}, \mathrm{Ho}, \mathrm{Er}, \mathrm{Tm}$ and $\mathrm{X}^{\mathrm{S}}=\mathrm{Zn}, \mathrm{Al}, \mathrm{Cu}, \mathrm{Co}, \mathrm{Ni}[3-13]$. Of the 35 possible $\mathrm{Mg}-\mathrm{X}^{\mathrm{L}}-\mathrm{X}^{\mathrm{S}}$ ternaries listed above, only 11 have reported LPSO formation, as summarized in Figure 5. This is likely a consequence of a focus on ${ }^{\mathrm{L}}=\mathrm{Zn}$ systems, particularly the Mg-Y-Zn system.

An important issue in predicting the properties for these LPSO structures with atomistic models such as density functional theory (DFT) is that their precise structure has remained elusive. The LPSO structure is readily observed to contain long range order along the c-axis. For many systems, the structure is, at first, of rhombohedral symmetry with 18 atomic layers per repeat unit (the 18R structure) and, after annealing, transforms into a different structure with hexagonal symmetry and 14 layers per repeat unit (the $14 \mathrm{H}$ structure)[7, 14]. 
However, it was only recently that complete structure models were proposed. The first, reported by Zhu et al. for Mg-Y-Zn[15], consists of alternating groups of HCP-stacked Mg planes (five planes for $14 \mathrm{H}$ and four for 18R) and pairs of ternary FCC-stacked Mg-Y-Zn planes. Importantly, the ternary planes were reported to be fully ordered chemically. The second structural model, reported by Egusa and Abe, for Mg-Y-Zn and Mg-Er-Zn[16], modified the 2011 model, replacing the HCP Mg planes adjacent to the FCC ternary planes with binary $\mathrm{Mg}-\mathrm{X}^{\mathrm{L}}$ planes, with the change in composition along the c-axis more gradual. In both models, the only difference between the $14 \mathrm{H}$ and $18 \mathrm{R}$ structures is the quantity of HCP Mg planes.

In our previous work[17], we compared the DFT-predicted thermodynamic stability of the two structure models[15, 16] in the Mg-Y-Zn system and found that (1) for both 14H and 18R structures the newer, "gradual" model of Egusa and Abe[16] was energetically preferred over the sharper one by Zhu et al.[15], (2) the $14 \mathrm{H}$ structure is more stable than $18 \mathrm{R}$, and (3) all of the calculated structures were metastable (i.e. they were higher in energy than combinations of other phases in the Mg-Y-Zn system). Hence, using these structural models, DFT calculations predict that LPSO structures are not thermodynamic ground states. This conclusion could be reconciled with the experimental observations of LPSO structures in one of two ways: either (i) the observed LPSO structures are, in fact, metastable, or (ii) these previous structural models or DFT calculations are incorrect.

Since our previous work, a third structure model has been proposed[18]. It has been observed that the "gradual" LPSO structure model, when relaxed in DFT, expands in such a way as to create a large interstitial site within the ternary ordered layers[18]. DFT calculations for this "interstitial" LPSO model in the Mg-Y-Zn system have shown that this structure is thermodynamically stable relative to the other phases[18]. Another recent work[19] examined with DFT various Y-Zn ordered clusters in the LPSO ternary layers, including interstitials. The stability of the interstitial model suggests this structure is more accurate than the previous sharp and gradual structure models and we can use 
this model to test the stability of a wide variety of LPSO precipitate chemistries in DFT.

In an effort to discover more affordable non-RE alloying elements which can form LPSO structures, we employ DFT calculations to predict the stability of LPSO structures in every LPSO-forming ternary system to examine the effect of chemistry on LPSO stability. We then extend the study to explore the possibility of novel non-RE elements capable of forming LPSO structures. We begin by exploring the thermodynamic stability of the interstitial LPSO structure model with DFT in detail for the Mg-Y-Zn system, finding that including $\mathrm{Mg}$ interstitials promotes the stability of the structure over the older models. We then systematically predict the stability of the interstitial LPSO structure in $85 \mathrm{RE}$-containing $\mathrm{Mg}-\mathrm{X}^{\mathrm{L}}-\mathrm{X}^{\mathrm{S}}$ ternary systems, for $\mathrm{X}^{\mathrm{L}}=\mathrm{RE}(\mathrm{Sc}, \mathrm{Y}, \mathrm{La}-\mathrm{Lu})$ and $\mathrm{X}^{\mathrm{S}}=\mathrm{Zn}, \mathrm{Al}, \mathrm{Cu}, \mathrm{Co}, \mathrm{Ni}$. For the 11 systems where LPSO phases are observed, our calculations predict all of these phases to be thermodynamically stable. In addition, we predict 41 stable RE-containing LPSO phases in systems where they have not been currently reported. These 41 as-yet-unobserved LPSO phases represent predictions awaiting experimental confirmation. From these results, we test the validity of previously proposed rules for LPSO forming systems, including the effect of the size of the $\mathrm{X}^{\mathrm{L}}$ element and the mixing energy between $\mathrm{Mg}$ and $\mathrm{X}^{\mathrm{L}}$ on the FCC lattice. These design rules are then used to predict several candidate non- $\mathrm{RE} \mathrm{X}^{\mathrm{L}}$ elements that may also form LPSO structures, which we then calculate with DFT. We predict the stability of LPSO for 55 non-REcontaining systems and find several systems for which LPSO phases are low in energy, competitive with thermodynamic stability. From these calculations, we predict that $\mathrm{X}^{\mathrm{L}}=\mathrm{Ca}, \mathrm{Sr}$, and Th are promising LPSO forming elements.

\section{Methodology}

DFT calculations are performed with the Vienna Ab-initio Simulation Package (VASP) [20, 21], employing the projected augmented wave method potentials[22] and the exchange and correlation functional of Perdew, Burke, and Ernzerhof[23]. 
All degrees of freedom for the crystal structures are relaxed, including volume, cell shape, and internal atomic coordinates, to determine the $0 \mathrm{~K}$ energetic ground state structure. An energy cutoff of $520 \mathrm{eV}$ and gamma-centered k-point meshes of around $8000 \mathrm{k}$-points per reciprocal atom are used in the relaxation. $\mathrm{k}$-space integration is performed by the first-order Methfessel-Paxton approach with a smearing width of $0.2 \mathrm{eV}$ during structural relaxation and then by the tetrahedron method with Blöchl corrections during a final, static calculation for accurate total energy. The f-electrons of the lanthanide elements were treated as core electrons, an approximation that has shown to produce accurate thermodynamic properties for lanthanide-containing structures[24-27]. Calculations for systems containing $\mathrm{Co}$ and $\mathrm{Ni}$ were spin polarized with an initialized ferromagnetic structure.

For an LPSO structure to be thermodynamically stable, it must be stable with respect to every combination of unary, binary, and ternary phases in its respective ternary system. We define the thermodynamic stability of an LPSO structure, $\Delta \mathrm{E}_{\text {stab }}($ LPSO), by:

$$
\Delta \mathrm{E}_{\text {stab }}(\text { LPSO })=\mathrm{E}(\text { LPSO })-\sum_{\mathrm{i}} \mathrm{N}_{\mathrm{i}} \mu_{\mathrm{i}}
$$

where $\mathrm{E}(\mathrm{x})$ is the DFT predicted total energy of structure $\mathrm{x}, \mathrm{N}_{\mathrm{i}}$ is the amount of element $i$, and $\mu_{\mathrm{i}}$ is the chemical potential of element $i$. To determine the set of $\mu_{\mathrm{i}}$ chemical potentials, we employ the following two facts: first, for a system in equilibrium, the chemical potential of each element must be the same in every stable phase; second, the total energy of a structure is simply the composition weighted sum of the constituent chemical potentials,

$$
\mathrm{E}(\mathrm{x})=\sum_{\mathrm{i}} \mathrm{N}_{\mathrm{i}} \mu_{\mathrm{i}}
$$

From these points, we construct a linear system of equations where Equation 2 is defined for each stable phase at the LPSO structure composition (excluding the LPSO structure itself) and solve for each $\mu_{\mathrm{i}}$. The formation energy, $\Delta \mathrm{E}_{\mathrm{F}}$, is 
defined similarly to $\Delta \mathrm{E}_{\mathrm{stab}}$ and Equation 3, but the $\mu_{\mathrm{i}}$ chemical potentials are determined from the elemental structures instead of the equilibrium structures.

To calculate the set of stable phases (i.e the convex hull), we have employed the Open Quantum Materials Database (OQMD)[28], a high-throughput DFT database of total energies for every crystal structure found in the International Crystal Structure Database (ICSD)[29, 30] with primitive cells less than 30 atoms and without partial site occupancy. For the $140 \mathrm{Mg}-\mathrm{X}^{\mathrm{L}}-\mathrm{X}^{\mathrm{S}}$ ternary systems examined in this work, this amounts to DFT calculations of over 3900 compounds. From this database of compounds, the most stable set of structures at a given composition, from which $\mu_{\mathrm{i}}$ are determined in Equation 3, are calculated by grand canonical linear programming (GCLP) [28, 31-33]. With GCLP, since both the composition and the free energy are linear as a function of quantity of different phases in a system, the set of phases that has the minimum total free energy at a given composition can be determined by linear programming.

To illustrate the application of Equation 3, the phases that are stable, excluding the LPSO structures, at the $14 \mathrm{H}-\mathrm{i} \mathrm{Mg}_{71} \mathrm{Y}_{8} \mathrm{Zn}_{6}$ LPSO composition are $\mathrm{Mg}, \mathrm{MgYZn}$, and $\mathrm{Mg}_{3} \mathrm{Y}$ (as listed in Table 8). The 14H-i structure will be defined in Section 3.1. By Equation 3, the stability of the $14 \mathrm{H}-\mathrm{i} \mathrm{Mg}_{71} \mathrm{Y}_{8} \mathrm{Zn}_{6}$ LPSO structure is the energy of the LPSO relative to the composition-weighted sum of the competing phases:

$$
\Delta \mathrm{E}_{\text {stab }}\left(\mathrm{Mg}_{71} \mathrm{Y}_{8} \mathrm{Zn}_{6}\right)=\mathrm{E}\left(\mathrm{Mg}_{71} \mathrm{Y}_{8} \mathrm{Zn}_{6}\right)-59 \mathrm{E}(\mathrm{Mg})-6 \mathrm{E}(\mathrm{MgYZn})-2 \mathrm{E}\left(\mathrm{Mg}_{3} \mathrm{Y}\right)
$$

The energy of this reaction, also given in Table 8 , is $-12 \mathrm{meV} /$ atom, where the negative value indicates the phase is stable. In other words, the $14 \mathrm{H}-\mathrm{i}$ $\mathrm{Mg}_{71} \mathrm{Y}_{8} \mathrm{Zn}_{6}$ LPSO structure is a stable phase as it lies $12 \mathrm{meV} /$ atom below the convex hull composed of $\mathrm{Mg}, \mathrm{MgYZn}$, and $\mathrm{Mg}_{3} \mathrm{Y}$.

It should be noted that the predicted stabilities are subject to the availability of crystal structures in the ICSD. For example, some of the experimentally observed ternary phases in the Mg-Y-Zn system (W- $\mathrm{Mg}_{3} \mathrm{Y}_{2} \mathrm{Zn}_{3}, \mathrm{Z}-\mathrm{Mg}_{28} \mathrm{Y}_{7} \mathrm{Zn}_{65}$, 
$\left.\mathrm{I}-\mathrm{Mg}_{3} \mathrm{YZn}_{6}, \mathrm{H}-\mathrm{Mg}_{15} \mathrm{Y}_{15} \mathrm{Zn}_{70}, \mathrm{X}-\mathrm{Mg}_{12} \mathrm{YZn}\right)[34,35]$ do not have fully determined structures in the ICSD, so they are not included in our study. Therefore, the convex hull energetics in this work should be consider an upper bound on the true convex hull (i.e. the convex hull energies could be lower than those in the current work but not higher). Consequently, the DFT stabilities for the LPSO structures in this work are a lower bound (i.e. the stability could be more positive but not more negative than currently predicted).

Although computationally demanding and outside the scope of the current work, crystal structure prediction tools[36-38] can be applied to such systems with unknown compounds to at least approximate the formation energies of the phases in a given ternary competing with the LPSO structure. We approach the problem of unexplored systems and structures by calculating simple ordered structures in the FCC, BCC, and HCP lattices for all systems in this work. The included simple structures consist of binary compounds $\left(\mathrm{L}_{2}, \mathrm{~L}_{0}, \mathrm{D}_{3}, \mathrm{~B} 2\right.$, $\mathrm{B}_{\mathrm{h}}$, and $\left.\mathrm{D}_{19}\right)$ and the ternary $\mathrm{X}_{2} \mathrm{YZ}$ Heusler compound. In this way, these prototype structures, although likely not on the true convex hull, may provide a better approximation for the convex hull energy in systems where experimentally determined crystal structures data may not be available. In other words, a predicted convex hull energy which includes a prototype will be more negative than without the prototype and closer to the true value. It appears this is an important consideration for the $\mathrm{Mg}-\mathrm{X}^{\mathrm{L}}-\mathrm{X}^{\mathrm{S}}$ ternaries considered in this work since most of their convex hulls from the OQMD at LPSO compositions contain prototypes. The sets of stable phases at every LPSO composition are given in Tables 8-12.

\section{Results and Discussion}

\subsection{Comparison of LPSO Structure Models}

The $14 \mathrm{H}$ and $18 \mathrm{R}$ gradual LPSO structures by Egusa and Abe[16] have stoichiometries of $\mathrm{Mg}_{70} \mathrm{X}_{8}^{\mathrm{L}} \mathrm{X}_{6}^{\mathrm{S}}$ and $\mathrm{Mg}_{58} \mathrm{X}_{8}^{\mathrm{L}} \mathrm{X}_{6}^{\mathrm{S}}$, respectively. The arrangement of the eight $\mathrm{X}^{\mathrm{L}}$ and six $\mathrm{X}^{\mathrm{S}}$ atoms within the four FCC stacked binary and 
ternary layers of the gradual LPSO structure model unit cell forms an $\mathrm{X}_{6}^{\mathrm{S}} \mathrm{X}_{8}^{\mathrm{L}}$ $\mathrm{L}_{2}$-arranged cluster in the $\mathrm{Mg}$ matrix, as shown in Figure 1 for $14 \mathrm{H}$. Egusa and Abe[16] noted significant displacement of the $\mathrm{X}^{\mathrm{L}}$ and $\mathrm{X}^{\mathrm{S}}$ atoms in this cluster occurred after DFT relaxation of the ideal structure, with the $\mathrm{X}^{\mathrm{L}}$ atoms moving towards the center of the cluster and the $\mathrm{X}^{\mathrm{S}}$ atoms moving away, reducing the $\mathrm{X}^{\mathrm{S}}-\mathrm{X}^{\mathrm{S}}$ interatomic distance. Later DFT work from the same authors showed that this relaxation creates a large interstitial site at the body center of the $\mathrm{L} 1_{2}$ cluster, and the inclusion of an interstitial atom on this site thermodynamically stabilizes the structure[18]. Analysis of the Mg-Y-Zn 14H and 18R gradual structures from our current calculations confirm this relaxation. The minimum nearest neighbor distances about the interstitial site (int) in the body center of the $\mathrm{L} 1_{2}$ cluster in the $14 \mathrm{H}$ structure are 3.16 and $3.40 \AA$ for the $i n t-Z n$ and int$\mathrm{Y}$ distances, respectively, large enough for an interstitial atom to be included. This interstitial site is also indicated in Figure 1. For comparison, the distance of the next largest interstitial site to a nearest neighbor is $2.25 \AA$, indicating that there exists only one large interstitial site in the gradual LPSO structure.

[Figure 1 about here.]

To test which species of interstitial atom $\left(\mathrm{Mg}, \mathrm{X}^{\mathrm{L}}\right.$, or $\left.\mathrm{X}^{\mathrm{S}}\right)$ is the most stable, we calculate the energy to insert interstitial atom i, $\Delta \mathrm{E}_{\text {int }}^{\mathrm{i}}$, for the three possible interstitial species in the $14 \mathrm{H}$ interstitial $\mathrm{Mg}$-Y-Zn structure, $\mathrm{Mg}_{70} \mathrm{Y}_{8} \mathrm{Zn}_{6}($ int $)$, where int is the interstitial atom:

$$
\begin{gathered}
\Delta \mathrm{E}_{\text {int }}^{\mathrm{Mg}}=\mathrm{Mg}_{70} \mathrm{Y}_{8} \mathrm{Zn}_{6}(\mathrm{Mg})-\mathrm{Mg}_{70} \mathrm{Y}_{8} \mathrm{Zn}_{6}-\mu_{\mathrm{Mg}}=-1.864 \mathrm{eV} / \mathrm{int} \\
\Delta \mathrm{E}_{\mathrm{int}}^{\mathrm{Y}}=\mathrm{Mg}_{70} \mathrm{Y}_{8} \mathrm{Zn}_{6}(\mathrm{Y})-\mathrm{Mg}_{70} \mathrm{Y}_{8} \mathrm{Zn}_{6}-\mu_{\mathrm{Y}}=-1.474 \mathrm{eV} / \mathrm{int} \\
\Delta \mathrm{E}_{\mathrm{int}}^{\mathrm{Zn}}=\mathrm{Mg}_{70} \mathrm{Y}_{8} \mathrm{Zn}_{6}(\mathrm{Zn})-\mathrm{Mg}_{70} \mathrm{Y}_{8} \mathrm{Zn}_{6}-\mu_{\mathrm{Zn}}=-1.032 \mathrm{eV} / \mathrm{int}
\end{gathered}
$$

For all three defect formation energies, the $\mu_{\mathrm{i}}$ elemental chemical potentials are determined from the same set of stable compounds in the Mg-Y-Zn system at the LPSO composition: $\mathrm{Mg}, \mathrm{MgYZn}$, and $\mathrm{Mg}_{3} \mathrm{Y}$. Note that the exper- 
imentally observed stable $\mathrm{Mg}$-rich $\mathrm{Mg}$-Y binary compound is $\mathrm{Mg}_{24} \mathrm{Y}_{5}$, but our DFT calculations predict $\mathrm{Mg}_{3} \mathrm{Y} \mathrm{D0} 0_{3}$ as more stable, in agreement with previous calculations[39]. $\mathrm{Mg}_{24} \mathrm{Y}_{5}$ lies $3 \mathrm{meV} /$ atom above the DFT convex hull, an energy difference that does not qualitatively affect the results in this work. All three interstitial defect formation energies are negative, indicating that they each stabilize the $14 \mathrm{H}$ gradual structure with their presence. Mg interstitials are predicted to be preferred as they have the most favorable formation energy and, thus, produce the most stable LPSO structure with respect to the other phases in the Mg-Y-Zn ternary system.

We calculate $\Delta \mathrm{E}_{\text {int }}^{\mathrm{Mg}}$ for the $\mathrm{X}^{\mathrm{L}}=\mathrm{RE}$ and $\mathrm{X}^{\mathrm{S}}=\mathrm{Al}, \mathrm{Zn}$ LPSO systems, shown in Figure 4. All the $\Delta \mathrm{E}_{\text {int }}^{\mathrm{Mg}}$ values are negative, indicating that the interstitial $\mathrm{Mg}$ atom promotes the stability of the LPSO structure, by as much as -2.109 $\mathrm{eV} /$ defect for the $\mathrm{Mg}-\mathrm{Gd}-\mathrm{Al}$ system. We also predict $\Delta \mathrm{E}_{\mathrm{int}}^{\mathrm{Mg}}$ for the $18 \mathrm{R}$ LPSO structure for a selection of ternary systems by:

$$
\Delta \mathrm{E}_{\mathrm{int}}^{\mathrm{Mg}}=\mathrm{Mg}_{58} \mathrm{X}_{8}^{\mathrm{L}} \mathrm{X}_{6}^{\mathrm{S}}(\mathrm{Mg})-\mathrm{Mg}_{58} \mathrm{X}_{8}^{\mathrm{L}} \mathrm{X}_{6}^{\mathrm{S}}-\mu(\mathrm{Mg})
$$

The resulting the $18 \mathrm{R} \Delta \mathrm{E}_{\text {int }}^{\mathrm{Mg}}$ values are given in parentheses, in $\mathrm{eV} /$ defect: $\mathrm{Mg}$ Gd-Zn(-1.846), Mg-Y-Cu(-1.6375), Mg-Y-Co(-1.698), Mg-Y-Ni(-1.623), Mg-Gd$\mathrm{Al}(-2.137)$. As with the $14 \mathrm{H}$ structures, $\mathrm{Mg}$ interstitials stabilize the $18 \mathrm{R}$ structure. Indeed, for every case in this work, the LPSO structure with the interstitial Mg atoms are more stable than their gradual model equivalent. Our DFT calculations lend strong support to the validity of the interstitial structure model proposed by Egusa and Abe[18]. Based on these results, we will focus the remainder of the work on the LPSO gradual structures containing Mg interstitials, hereafter referred to as $14 \mathrm{H}-\mathrm{i}$ and $18 \mathrm{R}-\mathrm{i}$. The DFT relaxed Mg-Y-Zn 14H-i and 18R-i crystal structures are given in Tables 1 and 2. The relaxed Mg-RE-X 14H-i and 18R-i crystal structure parameters are provided in Tables 3-7.

[Figure 2 about here.]

[Table 1 about here.] 
[Table 2 about here.]

[Table 3 about here.]

[Table 4 about here.]

[Table 5 about here.]

[Table 6 about here.]

[Table 7 about here.]

In precipitation experiments, LPSO systems are often observed to initially form the $18 \mathrm{R}$ structure and then transform to $14 \mathrm{H}$ after annealing[7, 14]. Mg$\mathrm{Gd}-\mathrm{Al}$ is a notable exception, where only the $18 \mathrm{R}$ structure has been observed[10]. In our previous work, we showed that our calculations are consistent with experiments for the $\mathrm{Mg}-\mathrm{Y}-\mathrm{Zn}$ system, where the $14 \mathrm{H}$ structure is more stable than $18 \mathrm{R}$ and $\mathrm{Mg}[17]$. A corresponding relationship between the $14 \mathrm{H}-\mathrm{i}$ and $18 \mathrm{R}-\mathrm{i}$ structures is given by the following transformation:

$$
2 \mathrm{Mg}_{59} \mathrm{X}_{8}^{\mathrm{L}} \mathrm{X}_{6}^{\mathrm{S}}[18 \mathrm{R}-\mathrm{i}]+12 \mathrm{Mg} \rightarrow \mathrm{Mg}_{71} \mathrm{X}_{8}^{\mathrm{L}} \mathrm{X}_{6}^{\mathrm{S}}[14 \mathrm{H}-\mathrm{i}]
$$

The DFT predicted energy for this transformation, $\Delta E_{18 \mathrm{R}-\mathrm{i} \rightarrow 14 \mathrm{H}-\mathrm{i}}$, for every $\mathrm{RE}$-containing LPSO system in this work $\left(\mathrm{X}^{\mathrm{L}}=\mathrm{RE}\right.$ and $\left.\mathrm{X}^{\mathrm{S}}=\mathrm{Zn}, \mathrm{Al}, \mathrm{Cu}, \mathrm{Co}, \mathrm{Ni}\right)$ is shown in Figure 3. A negative value for $\Delta E_{18 \mathrm{R}-\mathrm{i} \rightarrow 14 \mathrm{H}-\mathrm{i}}$ indicates the $14 \mathrm{H}$ i structure is more stable than $18 \mathrm{R}-\mathrm{i}$ and $\mathrm{Mg}$. For most of the systems, the $14 \mathrm{H}-\mathrm{i}$ structure is more stable, in agreement with experimental observation. Furthermore, for the first half of the Mg-RE-Al series, we predict that the 18R-i structure is preferred, consistent with experimental observation of a preference for 18R LPSO formation in the Mg-Gd-Al system[10]. This agreement with experiments, where available, is another indirect indication that the interstitial LPSO structure model is accurate and gives us confidence in DFT thermodynamic predictions for cases where no experimental data exists.

[Figure 3 about here.] 


\subsection{Thermodynamic Stability of $M g-R E-X^{\mathrm{S}}$ LPSO Structures}

The formation energies $\left(\Delta \mathrm{E}_{\mathrm{F}}\right)$ and stabilities $\left(\Delta \mathrm{E}_{\text {stab }}\right)$ of the Mg-RE-X LPSO structures are summarized in Figure 4. Nearly all Mg-RE-X ${ }^{S}$ LPSO phases have negative formation energies, indicating they are stable with respect to the elements - only the Mg-Eu-Co and Mg-Yb-Co LPSO formation energies are positive. However, a negative formation energy is not a sufficient condition for an LPSO structure to be stable. The LPSO structure must also be more stable than any combination of every other phase in the ternary system, as quantified by $\Delta \mathrm{E}_{\text {stab }}$. To predict $\Delta \mathrm{E}_{\text {stab }}$ of the LPSO structures, we determine the most stable set of competing phases at the $18 \mathrm{R}-\mathrm{i} \mathrm{Mg}_{59} \mathrm{X}_{8}^{\mathrm{L}} \mathrm{X}_{6}^{\mathrm{S}}$ and $14 \mathrm{H}-\mathrm{i}$ $\mathrm{Mg}_{71} \mathrm{X}_{8}^{\mathrm{L}} \mathrm{X}_{6}^{\mathrm{S}}$ compositions. These phases are provided in Tables 8-12. Several $14 \mathrm{H}$-i structures (and $18 \mathrm{R}-\mathrm{i}$ for $\mathrm{X}^{\mathrm{S}}=\mathrm{Al}$ ) have negative values of $\Delta \mathrm{E}_{\text {stab }}$, indicating they are thermodynamically stable, including Mg-Y-Zn. This stability is in contrast to our previous work[17] where, for $14 \mathrm{H} \mathrm{Mg-Y-Zn} \mathrm{LPSO} \mathrm{without}$ the interstitial, the structure lies $11 \mathrm{meV} /$ atom above the convex hull. $14 \mathrm{H}-\mathrm{i}$ Mg-Y-Zn, in this work, is $12 \mathrm{meV} /$ atom below the convex hull. Thus, using the new interstitial crystal structure[18], DFT predicts that LPSO structures, in many cases, are thermodynamic ground states.

[Table 8 about here.]

[Table 9 about here.]

[Table 10 about here.]

[Table 11 about here.]

[Table 12 about here.]

[Figure 4 about here.]

The stability of LPSO structures in all Mg-RE-X ${ }^{\mathrm{S}}$ ternary systems explored in the current work is summarized in Figure 5. Interestingly, regardless of which $\mathrm{X}^{\mathrm{S}}$ is present, the same set of heavier $\mathrm{RE} \mathrm{X}^{\mathrm{L}}$ elements generally appear 
to form stable LPSO structures: Y, Gd, Tb, Dy, Ho, Er, Tm, and Lu. As indicated in Figure 5, several other ternary systems, such as those containing $\mathrm{Nd}$ and Sm, are predicted to have nearly stable LPSO structures, lying less than $25 \mathrm{meV}$ above the convex hull ( $\mathrm{k}_{\mathrm{B}} \mathrm{T}$ at room temperature). Currently, LPSO phases have only been studied in very few ternaries for $\mathrm{X}^{\mathrm{S}} \neq \mathrm{Zn}[5,8,10$

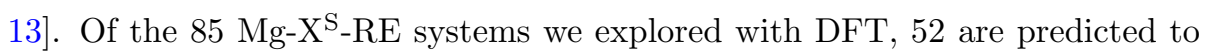
have thermodynamically stable LPSO structures. To our knowledge, only 11 LPSO-forming ternary systems have been reported in the literature[3-13], and we predict all 11 to contain stable LPSO structures. Therefore, we predict the existence of 41 new, as-yet-unobserved LPSO-forming ternary systems. We call for experimental investigation of these systems to confirm (or deny) the validity of our predictions.

[Figure 5 about here.]

\subsection{Thermodynamic Stability of Non-RE LPSO Structures}

Up to now, we have only discussed LPSO structures in ternary systems where $\mathrm{X}^{\mathrm{L}}=\mathrm{RE}$. Non-RE $\mathrm{X}^{\mathrm{L}}$ elements are highly desirable to reduce the cost of employing LPSO precipitate strengthening on an industrial scale. To predict with DFT every possible $\mathrm{Mg}-\mathrm{X}^{\mathrm{L}}-\mathrm{X}^{\mathrm{S}}$ system is prohibitively expensive given the large quantity of possible ternary systems. Therefore, we limit the current DFT exploration of non-RE LPSO systems to the five known $\mathrm{X}^{\mathrm{S}}$ elements and employ a simple screen (detailed below) on all possible $\mathrm{X}^{\mathrm{L}}$ elements with high-throughput DFT calculations that are less computationally more efficient than full calculations of LPSO stability. The set of promising $\mathrm{X}^{\mathrm{L}}$ elements which pass this screen is sufficiently small for DFT predictions of stability to be performed. We conclude by testing the predicted DFT LPSO stabilities with several observed $\mathrm{X}^{\mathrm{L}}$ trends for LPSO formation[7] to investigate why only specific $\mathrm{X}^{\mathrm{L}}$ elements form stable LPSO structures.

We screen candidate $\mathrm{X}^{\mathrm{L}}$ elements for LPSO formation with what we assume

to be the most important factor contributing to the ability of an $\mathrm{X}^{\mathrm{L}}$ element to 
form a stable LPSO structure: the size mismatch of the element relative to $\mathrm{Mg}$, noted as an important criteria for $\mathrm{X}^{\mathrm{L}} \mathrm{LPSO}$ structure formation[7]. To quantify this mismatch, Kawamura et al.[7] used the mismatch between elemental atomic radii. From our DFT predicted atomic radii (calculated by taking half the nearest neighbor distance in the $0 \mathrm{~K}$ ground state crystal structure), the atomic radius mismatch of the observed $\mathrm{X}^{\mathrm{L}}$ elements ( $\mathrm{Y}$ and the later REs, as given in Figure 5) range between 8.5-12\% larger than Mg. After calculating this quantity for 88 elements, ${ }^{1}$ only three have radius mismatches near this range: $\mathrm{Pb}, \mathrm{Tl}$, and Th. The stability of LPSO structures for these elements serving as $\mathrm{X}^{\mathrm{L}}$ was predicted with DFT. Shown in Figures 6 and 5 and given in Tables 8-12, the stabilities for the $\mathrm{Pb}$ - and Tl-containing LPSO structures are very positive, indicating they will not form LPSO structures. Th-containing LPSO structures, on the other hand, are predicted to be stable. However, thorium's radioactive nature presumably limits the usefulness of any potential LPSO structures containing the element.

[Figure 6 about here.]

We find a better indicator of the $\mathrm{Mg} / \mathrm{X}^{\mathrm{L}}$ size mismatch towards LPSO stability with the impurity volume, $\mathrm{V}_{\mathrm{Imp}}^{\mathrm{X}^{\mathrm{L}}}$. This quantity is defined by:

$$
\mathrm{V}_{\mathrm{Imp}}^{\mathrm{X}}=\mathrm{V}\left(\mathrm{Mg}_{149} \mathrm{X}_{1}\right)-\mathrm{V}\left(\mathrm{Mg}_{150}\right)
$$

where $\mathrm{V}\left(\mathrm{Mg}_{150}\right)$ and $\mathrm{V}\left(\mathrm{Mg}_{149} \mathrm{X}_{1}\right)$ are the volumes of a 150 atom HCP supercell containing $\mathrm{Mg}_{150}$ and $\mathrm{Mg}_{149} \mathrm{X}$, respectively. In our previous work, supercells of 150 atoms were found to produce values for $\mathrm{V}_{\text {Imp }}$ converged with respect to supercell size[26]. Predicted for many elements in our previous works[26, 40], the impurity volume of $\mathrm{X}^{\mathrm{L}}$ in $\mathrm{Mg}$ captures the interaction of the alloying element with the Mg matrix. Currently, we have calculated the DFT impurity volume for every element with a VASP potential. As shown in Figure $7, \mathrm{~V}_{\mathrm{Imp}}^{\mathrm{X}^{\mathrm{L}}}$, as an

\footnotetext{
${ }^{1}$ These 88 elements are those with a GGA-PBE potential provided with version 5.3.2 of VASP.
} 
LPSO-forming criteria, clusters all the known $\mathrm{X}^{\mathrm{L}}$ elements ( $\mathrm{Y}$ and the later REs, as given in Figure 5) into a single group (between 11.1 and $14.6 \AA^{3}$ ). Therefore, we predict with DFT the LPSO stability of several non-RE solutes with impurity volumes near $\mathrm{RE}$ values, specifically $\mathrm{K}, \mathrm{Sr}, \mathrm{Ca}, \mathrm{Na}, \mathrm{Sb}, \mathrm{Pb}, \mathrm{Bi}$, and $\mathrm{Pa}$. These stabilities are shown in Figure 6 and given in Tables 8-12. Most of these LPSO structures are found to be metastable, but some come energetically close to the $\mathrm{T}=0 \mathrm{~K}$ ground state convex hull, as shown in Figure 5, particularly Ca- and Srcontaining systems. In these systems, finite-temperature effects could stabilize LPSO structures. Our results suggest that $\mathrm{Ca}$ - and Sr-containing systems are promising and should be explored experimentally for possible new non-RE LPSO phases as they lie near the convex hull (2 meV/atom below the hull in the MgCa-Zn system).

\subsection{Testing Proposed Design Rules for LPSO Stability}

Kawamura et al.[7] observed several trends amongst LPSO-forming $\mathrm{X}^{\mathrm{L}}$ elements: (1) $\mathrm{X}^{\mathrm{L}}$ is larger than $\mathrm{Mg}$, (2) the mixing enthalpy between $\mathrm{Mg} / \mathrm{X}^{\mathrm{L}}$ and $\mathrm{X}^{\mathrm{L}} / \mathrm{X}^{\mathrm{S}}$ is favorable, (3) $\mathrm{X}^{\mathrm{L}}$ has the HCP structure at room temperature, and (4) $\mathrm{X}^{\mathrm{L}}$ is moderately soluble in $\mathrm{Mg}$. The first trend was used as the screening criteria for choosing non-RE elements. With our DFT calculated energetics database of LPSO structures in 85 RE- and 50 non-RE-containing ternary systems, the remaining trends can be examined more closely and used to elucidate why RE $\mathrm{X}^{\mathrm{L}}$ elements form stable LPSO structure whereas others do not.

The second proposed trend is that the $\mathrm{Mg}-\mathrm{X}^{\mathrm{L}}$ and $\mathrm{X}^{\mathrm{L}}-\mathrm{X}^{\mathrm{S}}$ binary systems exhibit favorable mixing thermodynamics. This trend had been observed from results of the Miedema model[7]. The favorable interactions between these elements may promote the formation of the LPSO, as $\mathrm{Mg}-\mathrm{X}^{\mathrm{L}}$ and $\mathrm{X}^{\mathrm{L}}-\mathrm{X}^{\mathrm{S}}$ nearestneighbor bonds are present in the binary and ternary layers of the LPSO structure. Unlike predictions of the Miedema model, DFT calculations of the formation energies of simple ordered compounds can estimate binary interactions for a particular lattice. As the $\mathrm{X}^{\mathrm{L}}$ atoms bond with $\mathrm{Mg}$ and $\mathrm{X}^{\mathrm{S}}$ on both $\mathrm{HCP}$ and FCC lattices in the LPSO structure, $\mathrm{L} 1_{2}$ and $\mathrm{D} 0_{19}$ formation energies for many 
possible $\mathrm{Mg}-\mathrm{X}^{\mathrm{L}}$ and $\mathrm{X}^{\mathrm{L}}-\mathrm{X}^{\mathrm{S}}$ systems were calculated with $\mathrm{DFT}$. The $\mathrm{Mg}_{3} \mathrm{X} \mathrm{L1} 1_{2}$ formation energy, $\Delta \mathrm{E}_{\mathrm{F}}^{\mathrm{Mg}_{3} \mathrm{X}}$, appeared to be the best indicator for whether an $\mathrm{X}^{\mathrm{L}}$ element can contribute to a stable LPSO structure, by clustering observed $\mathrm{X}^{\mathrm{L}}$ elements ( $\mathrm{Y}$ and the later REs, as given in Figure 5) with similar values. As seen in Figure 7 , all observed $\mathrm{X}^{\mathrm{L}}$ elements have negative $\mathrm{Mg}_{3} \mathrm{X} \mathrm{L1} 1_{2}$ formation energies, between -34 and $-76 \mathrm{meV} /$ atom.

[Figure 7 about here.]

Interestingly, either $\Delta \mathrm{E}_{\mathrm{F}}^{\mathrm{Mg}_{3} \mathrm{X}}$ or $\mathrm{V}_{\mathrm{Imp}}^{\mathrm{X}}$ alone are not sufficient indicators of whether an $\mathrm{X}^{\mathrm{L}}$ element will form a stable LPSO structure. For instance, $\mathrm{Pb}$ is predicted to have formation energies in the range of the observed $\mathrm{X}^{\mathrm{L}}$ elements, but, from Figure 6, Pb forms metastable LPSO structures. From Figure 7, $\mathrm{Pb}$ has a smaller impurity volume than the observed $\mathrm{RE} \mathrm{X}^{\mathrm{L}}$ elements. $\mathrm{Pa}$, conversely, has an impurity volume similar to the observed $\mathrm{X}^{\mathrm{L}}$ elements but has a very unfavorable mixing energy, also resulting in metastable LPSO structures. As seen in Figure 7, of all the non-RE elements studied in this work, Ca is nearest to satisfying both constraints, perhaps explaining why Ca-containing LPSO structures are predicted to have competitive stabilities. Therefore, we find that the impurity volume and $\mathrm{X}^{\mathrm{L}}-\mathrm{Mg}$ FCC mixing energy together serve as excellent criteria for determining LPSO formation, including, within a certain range, all stable $\mathrm{X}^{\mathrm{L}}$ elements and excluding all others, as indicated by the intersection of the two shaded regions in Figure 7. The heavy RE elements are unique in that they satisfy both criteria.

The remaining two trends of Kawamura et al.[7] can be explored from direct experimental observations. The third trend is that all known $\mathrm{X}^{\mathrm{L}}$ elements appear to be HCP at room temperature. Every HCP RE element has been found to form LPSO structures, except for Sc and Lu which, to our knowledge, have not been explored. From our DFT results, we predict that Sc- and Lucontaining LPSO structures are stable. Non-RE HCP elements include Be, Ti, $\mathrm{Zr}, \mathrm{Tc}, \mathrm{Ru}, \mathrm{Hf}, \mathrm{Re}, \mathrm{Os}$, and Tl. From our predictions of the impurity volume, these elements are all smaller than $\mathrm{Mg}$, except for $\mathrm{Tl}$, which is only slightly 
larger than Mg. With an impurity volume about $90 \%$ smaller than the values for the observed $\mathrm{X}^{\mathrm{L}}$ elements (see Figure 7), $\mathrm{Tl}$ is predicted to form metastable LPSO structures (see Figure 6). This result shows that there are no non-RE $\mathrm{HCP}$ elements that also have impurity volumes in the range of the RE elements. $\mathrm{Ca}, \mathrm{Sr}$, and $\mathrm{Th}$, which are the promising LPSO forming $\mathrm{X}^{\mathrm{L}}$ elements discussed earlier, are not HCP. However, DFT calculations of HCP Ca and Sr predict it to be very close energetically to FCC Ca and $\mathrm{Sr}$ (within $5 \mathrm{meV}$ /atom or less)[28, 41]. The fourth trend is that some moderate degree of solubility of $\mathrm{X}^{\mathrm{L}}$ in $\mathrm{Mg}$ is present. From the observed $\mathrm{X}^{\mathrm{L}}$ elements, the solubility at the eutectic temperature varies between 3.4 and 6.9 at.\%[42]. The solubility of $\mathrm{Ag}$ lies in this range, but the impurity volume of $\mathrm{Ag}$ is negative. Again, $\mathrm{Ca}$ and Th do not satisfy these conditions, exhibiting solubilities of 0.44 and 0.52 at.\%, respectively[42].

Ultimately, of the 11 non-RE $\mathrm{X}^{\mathrm{L}}$ elements studied in this work, only $\mathrm{Ca}, \mathrm{Sr}$, and Th are found to form low-energy stable and/or metastable structures competitive with the thermodynamic ground state, at least with the five $\mathrm{X}^{\mathrm{S}}$ elements presently considered. Although we predict Th-containing LPSO structures to have stabilities comparable to those containing REs, Th exhibits an impurity volume and mixing energy that makes it an unlikely LPSO-former. As no MgTh- $\mathrm{X}^{\mathrm{S}}$ ternary compounds or phase diagrams have been reported[29, 30, 42], the prediction of stable Th-containing LPSO structures is likely an indication our DFT database of competing structures is incomplete for $\mathrm{Mg}-\mathrm{X}^{\mathrm{S}}$-Th ternary systems. Previous studies on the Mg-Ca-Zn system[43-46] have not found an LPSO structure, although the nominal alloy compositions are different from those for typical LPSO systems (e.g. $\mathrm{Mg}_{97} \mathrm{RE}_{2} \mathrm{Zn}_{1}[7]$ ). One study[45] examined the age hardening response for 0.3 at.\% Ca with varying amounts of $\mathrm{Zn}$ and found 0.6 at.\% $\mathrm{Zn}$ gives the best response, with peak hardness coinciding with monolayer G.P. zones aligned along basal planes. A recent study[46] of Mg-2.4Zn-3.2Ca (at.\%) using rapid solidification/powder metallurgy, a common approach to forming LPSO structures, did not report LPSO formation, although again, the nominal alloy composition is different from other LPSO alloys. With 
regard to the Mg-Zn-Sr system, no ternary crystal structures or phase diagrams have been reported[29, 30, 42]. Only recently have Mg alloys containing $\mathrm{Zn}$ and Sr been investigated[47, 48], as a potential medical implant material. The study by Brar et al.[48] examined a series of cast alloys at Mg-(0.8-2.3)Zn-0.1Sr (at.\%) compositions, finding Mg-rich ternary phases of composition $\mathrm{Mg}_{70} \mathrm{Zn}_{25} \mathrm{Sr}_{5}$ and $\mathrm{Mg}_{71} \mathrm{Zn}_{23} \mathrm{Sr}_{6}$. Their crystal structures were not reported. However, a later study by Guan et al.[47] investigated a Mg-1.5Zn-0.3Sr (at.\%) cast alloy and found only binary precipitates. Even if LPSO structures do not form in these non-RE systems, $\mathrm{Ca}$ and $\mathrm{Sr}$ may still prove useful as an alloying element to reduce the RE content in LPSO precipitates without dramatically degrading the stability of the phase (e.g. adding Ca to the Mg-Y-Zn LPSO structure may allow reducing the Y-content of the alloy without greatly reducing the volume fraction of LPSO precipitates).

\section{Summary}

We have predicted, with DFT, the properties of many $\mathrm{Mg}-\mathrm{X}^{\mathrm{L}}-\mathrm{X}^{\mathrm{S}}$ LPSO structures: 85 systems consisting of $\mathrm{X}^{\mathrm{L}}=\mathrm{RE}$ and $\mathrm{X}^{\mathrm{S}}=\mathrm{Zn}, \mathrm{Al}, \mathrm{Cu}, \mathrm{Co}, \mathrm{Ni}$. We find that the interstitial $14 \mathrm{H}-\mathrm{i}$ and $18 \mathrm{R}-\mathrm{i}$ LPSO structure models are energetically preferred to the previously published gradual structure model for every system we tested. Using these interstitial LPSO structures, we demonstrate that LPSO phases are thermodynamically stable in several ternary systems, specifically when $\mathrm{X}^{\mathrm{L}}$ is $\mathrm{Y}$ or a heavy RE element. We predict LPSO structures to be stable for every system where they are observed. Which $\mathrm{X}^{\mathrm{L}}$ elements form stable LPSO structures appear to be generally independent of the five $\mathrm{X}^{\mathrm{S}}$ elements in the current work, suggesting that there are several novel LPSO systems to explore, as summarized in Figure 5.

On the basis of the size mismatch between $\mathrm{Mg}$ and $\mathrm{X}^{\mathrm{L}}$, quantified by the impurity volume, several potential $\mathrm{X}^{\mathrm{L}}$ elements(Tl, $\mathrm{Sb}, \mathrm{Pb}, \mathrm{Na}, \mathrm{Te}, \mathrm{Bi}, \mathrm{Pa}, \mathrm{Ca}$, Th, K, Sr) have been explored, amounting to 50 non-RE ternary LPSO systems. These results have been used to examine previously proposed trends of $\mathrm{X}^{\mathrm{L}}$ 
elements that form LPSO structures, particularly the size mismatch and mixing energy between $\mathrm{Mg}$ and $\mathrm{X}^{\mathrm{L}}$. We find that the impurity volume and $\mathrm{X}^{\mathrm{L}}-\mathrm{Mg}$ FCC mixing energy together serve as excellent criteria determining LPSO formation, including, within a certain range, all stable $\mathrm{X}^{\mathrm{L}}$ elements and excluding all others. Of all explored non-RE LPSO ternary systems, Ca-, Sr-, and Th-containing LPSO structures are the most competitive with the ground state. Ca- and Srcontaining LPSO systems are suggested for further experimental study as an alternative to or addition to RE alloying.

\section{Acknowledgements}

Funding support provided by the Ford-Boeing-Northwestern Alliance. Calculations were performed on the Northwestern University high performance computing system, Quest. Many thanks to Don Shih, Bita Ghaffari, and Haruyuki Inui for fruitful discussions. We would also like to thank Daisuke Egusa and Eiji Abe at the University of Tokyo for discussions regarding the interstitial LPSO structure. 


\section{References}

[1] Y. Kawamura, K. Hayashi, A. Inoue, T. Masumoto, Materials Transactions 42 (2001) 1172-1176.

[2] A. Inoue, Y. Kawamura, M. Matsushita, K. Hayashi, J. Koike, Journal of Materials Research 16 (2001) 1894-1900.

[3] K. Amiya, T. Ohsuna, A. Inoue, Materials Transactions 44 (2003) 21512156.

[4] M. Yamasaki, T. Anan, S. Yoshimoto, Y. Kawamura, Scripta Materialia 53 (2005) 799-803.

[5] Y. Kawamura, T. Kasahara, S. Izumi, M. Yamasaki, Scripta Materialia 55 (2006) 453-456.

[6] K. Yamada, Y. Okubo, M. Shiono, H. Watanabe, Materials Transactions 47 (2006) 1066-1070.

[7] Y. Kawamura, M. Yamasaki, Materials Transactions 48 (2007) 2986-2992.

[8] T. Itoi, K. Takahashi, H. Moriyama, M. Hirohashi, Scripta Materialia 59 (2008) 1155-1158.

[9] J. Nie, K. Ohishi, X. Gao, K. Hono, Acta Materialia 56 (2008) 6061-6076.

[10] H. Yokobayashi, K. Kishida, H. Inui, M. Yamasaki, Y. Kawamura, Acta Materialia 59 (2011) 7287-7299.

[11] S.-B. Mi, Q.-Q. Jin, Scripta Materialia 68 (2013) 635-638.

[12] Q.-Q. Jin, C.-F. Fang, S.-B. Mi, Journal of Alloys and Compounds 7 (2013).

[13] Z. Leng, J. Zhang, T. Yin, L. Zhang, S. Liu, M. Zhang, R. Wu, Materials Science and Engineering: A In Press (2013).

[14] T. Itoi, T. Seimiya, Y. Kawamura, M. Hirohashi, Scripta Materialia 51 (2004) 107-111.

[15] Y. Zhu, A. Morton, J. Nie, Acta Materialia 58 (2010) 2936-2947.

[16] D. Egusa, E. Abe, Acta Materialia 60 (2012) 166-178.

[17] J. Saal, C. Wolverton, Scripta Materialia 67 (2012) 798-801.

[18] D. Egusa, E. Abe, Presented at LPSO conference at Sapporo, October 2, $2012(2012)$.

[19] S.-Y. Ma, L.-M. Liu, S.-Q. Wang, Journal of Materials Science (2012).

[20] G. Kresse, J. Furthmuller, Physical Review B 54 (1996) 11169. 
[21] G. Kresse, J. Furthmuller, Computational Materials Science 6 (1996) 1550.

[22] G. Kresse, D. Joubert, Physical Review B 59 (1999) 1758-1775.

[23] J. P. Perdew, K. Burke, M. Ernzerhof, Physical Review Letters 77 (1996) 3865 .

[24] M. Gao, A. Rollett, M. Widom, Physical Review B 75 (2007) 174120.

[25] Z. Mao, D. N. Seidman, C. Wolverton, Acta Materialia 59 (2011) 36593666 .

[26] J. Saal, C. Wolverton, Acta Materialia 60 (2012) 5151-5159.

[27] A. Issa, J. Saal, C. Wolverton Submitted (2013).

[28] J. Saal, S. Kirklin, B. Meredig, A. Thompson, J. Doak, C. Wolverton Under Prep (2013).

[29] G. Bergerhoff, R. Hundt, R. Sievers, I. D. Brown, Journal of Chemical Information and Modeling 23 (1983) 66-69.

[30] A. Belsky, M. Hellenbrandt, V. L. Karen, P. Luksch, Acta Crystallographica Section B Structural Science 58 (2002) 364-369.

[31] C. Wolverton, V. Ozolinš, Physical Review B 75 (2007) 1-15.

[32] a. R. Akbarzadeh, V. Ozolinš, C. Wolverton, Advanced Materials 19 (2007) 3233-3239.

[33] S. Kirklin, B. Meredig, C. Wolverton, Advanced Energy Materials 3 (2013) 252-262.

[34] G. Shao, V. Varsani, Z. Fan, Calphad 30 (2006) 286-295.

[35] A. Hamaya, T. Horiuchi, Y. Oohira, S. Minamoto, S. Miura, N. Sakaguchi, Materials Transactions 54 (2013) 641-646.

[36] A. R. Oganov, C. W. Glass, The Journal of chemical physics 124 (2006) 244704 .

[37] B. Meredig, C. Wolverton, Nature materials 12 (2013) 123-7.

[38] G. Trimarchi, A. Zunger, Physical Review B 75 (2007) 104113.

[39] X. Tao, Y. Ouyang, H. Liu, Y. Feng, Y. Du, Y. He, Z. Jin, Journal of Alloys and Compounds 509 (2011) 6899-6907.

[40] D. Shin, C. Wolverton, Acta Materialia 58 (2010) 531-540.

[41] Y. Wang, S. Curtarolo, C. Jiang, R. Arroyave, T. Wang, G. Ceder, L. Q. Chen, Z. K. Liu, Calphad 28 (2004) 79-90. 
[42] P. Villars, H. Okamoto, K. Cenzual, ASM Alloy Phase Diagrams Center, 2006.

[43] H. Somekawa, T. Mukai, Materials Science and Engineering: A 459 (2007) $366-370$.

[44] Y.-N. Zhang, D. Kevorkov, J. Li, E. Essadiqi, M. Medraj, Intermetallics 18 (2010) 2404-2411.

[45] K. Oh-ishi, R. Watanabe, C. Mendis, K. Hono, Materials Science and Engineering: A 526 (2009) 177-184.

[46] T. Zhou, M. Yang, Z. Zhou, J. Hu, Z. Chen, Journal of Alloys and Compounds 560 (2013) 161-166.

[47] R.-g. Guan, A. F. Cipriano, Z.-y. Zhao, J. Lock, D. Tie, T. Zhao, T. Cui, H. Liu, Materials Science and Engineering: C (2013).

[48] H. S. Brar, J. Wong, M. V. Manuel, Journal of the mechanical behavior of biomedical materials 7 (2012) 87-95. 
Table 1: DFT relaxed atomic positions for the $\mathrm{Mg}_{71} \mathrm{Y}_{8} \mathrm{Zn}_{6}$ 14H-i LPSO structure, with spacegroup $\mathrm{P} 6_{3} / \mathrm{mcm}$ (193) and lattice parameters a $=11.15 \AA$ $\mathrm{c}=36.36 \AA$.

\begin{tabular}{llccc}
\hline \hline Atom & site & $\mathrm{x}$ & $\mathrm{y}$ & $\mathrm{z}$ \\
\hline $\mathrm{Mg} 1$ & $24 \mathrm{l}$ & 0.165 & 0.655 & 0.037 \\
Mg2 & $24 \mathrm{l}$ & 0.830 & 0.169 & 0.110 \\
Mg3 & $24 \mathrm{l}$ & 0.165 & 0.663 & 0.180 \\
$\mathrm{Mg} 4$ & $12 \mathrm{k}$ & 0.494 & 0.000 & 0.108 \\
Mg5 & $12 \mathrm{k}$ & 0.836 & 0.000 & 0.179 \\
$\mathrm{Mg} 6$ & $12 \mathrm{k}$ & 0.329 & 0.000 & 0.180 \\
Mg7 & $12 \mathrm{j}$ & 0.168 & 0.332 & 0.250 \\
Mg8 & $8 \mathrm{~h}$ & 0.333 & 0.667 & 0.108 \\
Mg9 & $6 \mathrm{~g}$ & 0.498 & 0.000 & 0.250 \\
Mg10 & $4 \mathrm{c}$ & 0.333 & 0.667 & 0.250 \\
Mg11 & $2 \mathrm{a}$ & 0.000 & 0.000 & 0.250 \\
Mg12 int & $2 \mathrm{~b}$ & 0.000 & 0.000 & 0.000 \\
$\mathrm{Zn}$ & $12 \mathrm{k}$ & 0.777 & 0.000 & 0.049 \\
Y1 & $12 \mathrm{k}$ & 0.293 & 0.000 & 0.031 \\
Y2 & $4 \mathrm{e}$ & 0.000 & 0.000 & 0.096
\end{tabular}


Table 2: DFT relaxed atomic positions for the $\mathrm{Mg}_{59} \mathrm{Y}_{8} \mathrm{Zn}_{6}$ 18R-i LPSO structure, with spacegroup $\mathrm{C} 2 / \mathrm{m}(12)$ and lattice parameters $\mathrm{a}=11.15 \AA \mathrm{b}=19.34 \AA$ $\mathrm{c}=16.08 \AA \beta=76.49^{\circ}$.

\begin{tabular}{llccc}
\hline \hline Atom & site & $\mathrm{x}$ & $\mathrm{y}$ & $\mathrm{z}$ \\
\hline Mg1 & $8 \mathrm{j}$ & 0.059 & 0.918 & 0.918 \\
Mg2 & $8 \mathrm{j}$ & 0.053 & 0.752 & 0.917 \\
Mg3 & $8 \mathrm{j}$ & 0.056 & 0.583 & 0.916 \\
Mg4 & $8 \mathrm{j}$ & 0.306 & 0.832 & 0.918 \\
Mg5 & $8 \mathrm{j}$ & 0.305 & 0.665 & 0.919 \\
Mg6 & $8 \mathrm{j}$ & 0.084 & 0.834 & 0.751 \\
Mg7 & $8 \mathrm{j}$ & 0.084 & 0.670 & 0.756 \\
Mg8 & $8 \mathrm{j}$ & 0.330 & 0.915 & 0.756 \\
Mg9 & $8 \mathrm{j}$ & 0.330 & 0.748 & 0.751 \\
Mg10 & $8 \mathrm{j}$ & 0.840 & 0.915 & 0.756 \\
Mg11 & $8 \mathrm{j}$ & 0.191 & 0.828 & 0.586 \\
Mg12 & $8 \mathrm{j}$ & 0.956 & 0.918 & 0.586 \\
Mg13 & $8 \mathrm{j}$ & 0.938 & 0.755 & 0.586 \\
Mg14 & $4 \mathrm{i}$ & 0.310 & 0.000 & 0.918 \\
Mg15 & $4 \mathrm{i}$ & 0.803 & 0.000 & 0.916 \\
Mg16 & $4 \mathrm{i}$ & 0.089 & 0.000 & 0.751 \\
Mg17 int & $2 \mathrm{~d}$ & 0.000 & 0.500 & 0.500 \\
Zn1 & $8 \mathrm{j}$ & 0.427 & 0.888 & 0.614 \\
Zn2 & $4 \mathrm{i}$ & 0.760 & 0.000 & 0.615 \\
Y1 & $4 \mathrm{j}$ & 0.170 & 0.647 & 0.573 \\
Y2 & $4 \mathrm{i}$ & 0.574 & 0.000 & 0.724 \\
Y3 & $4 \mathrm{i}$ & 0.232 & 0.000 & 0.572
\end{tabular}


Table 3: DFT relaxed lattice parameters for the $\mathrm{Mg}-\mathrm{X}^{\mathrm{L}}-\mathrm{Zn}$ LPSO structures, in $\AA$.

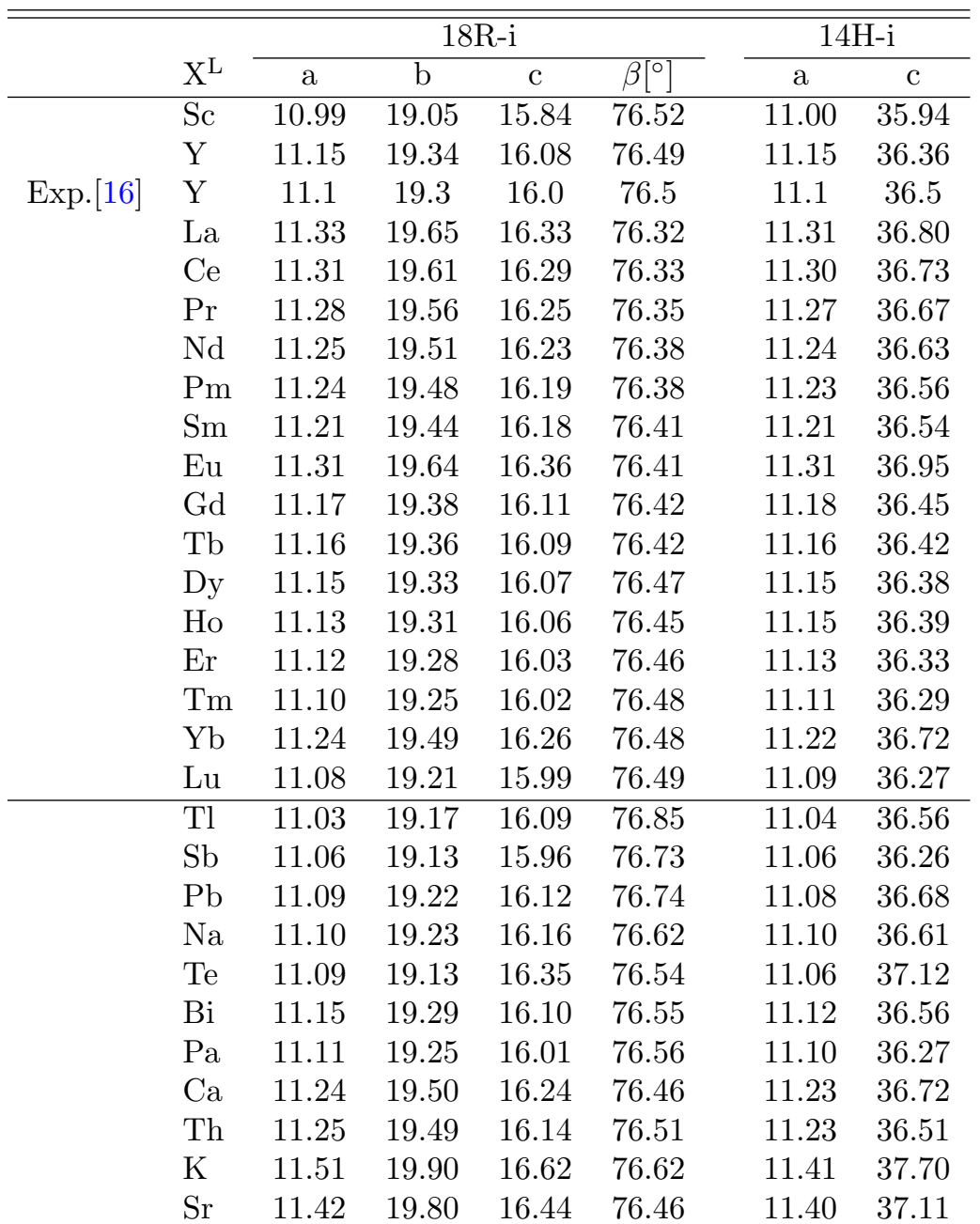


Table 4: DFT relaxed lattice parameters for the $\mathrm{Mg}-\mathrm{X}^{\mathrm{L}}-\mathrm{Al}$ LPSO structures, in $\AA$.

\begin{tabular}{lccccccc}
\hline \hline & \multicolumn{9}{c}{$18 \mathrm{R}-\mathrm{i}$} & & \multicolumn{2}{c}{$14 \mathrm{H}-\mathrm{i}$} \\
\cline { 2 - 4 } $\mathrm{X}^{\mathrm{L}}$ & $\mathrm{a}$ & $\mathrm{b}$ & $\mathrm{c}$ & $\beta\left[^{\circ}\right]$ & & $\mathrm{a}$ & $\mathrm{c}$ \\
\hline $\mathrm{Sc}$ & 11.03 & 19.11 & 15.90 & 76.58 & & 11.04 & 36.04 \\
$\mathrm{Y}$ & 11.21 & 19.41 & 16.10 & 76.47 & & 11.19 & 36.42 \\
$\mathrm{La}$ & 11.41 & 19.75 & 16.32 & 76.36 & & 11.37 & 36.80 \\
$\mathrm{Ce}$ & 11.39 & 19.71 & 16.29 & 76.36 & & 11.35 & 36.75 \\
$\mathrm{Pr}$ & 11.35 & 19.65 & 16.25 & 76.38 & & 11.32 & 36.69 \\
$\mathrm{Nd}$ & 11.33 & 19.61 & 16.23 & 76.40 & & 11.30 & 36.61 \\
$\mathrm{Pm}$ & 11.30 & 19.57 & 16.20 & 76.43 & & 11.27 & 36.58 \\
$\mathrm{Sm}$ & 11.28 & 19.53 & 16.18 & 76.44 & & 11.26 & 36.54 \\
$\mathrm{Eu}$ & 11.42 & 19.81 & 16.42 & 76.41 & & 11.39 & 37.02 \\
$\mathrm{Gd}$ & 11.24 & 19.46 & 16.14 & 76.48 & & 11.23 & 36.48 \\
$\mathrm{~Tb}$ & 11.21 & 19.42 & 16.11 & 76.48 & & 11.21 & 36.45 \\
$\mathrm{Dy}$ & 11.20 & 19.40 & 16.10 & 76.50 & & 11.20 & 36.44 \\
$\mathrm{Ho}$ & 11.19 & 19.37 & 16.09 & 76.50 & & 11.18 & 36.41 \\
$\mathrm{Er}$ & 11.17 & 19.36 & 16.08 & 76.53 & & 11.17 & 36.39 \\
$\mathrm{Tm}$ & 11.16 & 19.34 & 16.07 & 76.55 & & 11.16 & 36.37 \\
$\mathrm{Yb}$ & 11.32 & 19.63 & 16.30 & 76.49 & & 11.29 & 36.82 \\
$\mathrm{Lu}$ & 11.13 & 19.30 & 16.05 & 76.56 & & 11.13 & 36.35 \\
\hline $\mathrm{Tl}$ & 11.03 & 19.13 & 16.19 & 76.94 & & 11.03 & 36.80 \\
$\mathrm{Sb}$ & 11.07 & 19.19 & 16.14 & 76.81 & & 11.07 & 36.58 \\
$\mathrm{~Pb}$ & 11.14 & 19.30 & 16.10 & 76.61 & & 11.13 & 36.52 \\
$\mathrm{Na}$ & 11.17 & 19.35 & 16.19 & 76.62 & & 11.15 & 36.71 \\
$\mathrm{Te}$ & 11.10 & 19.26 & 16.44 & 77.26 & & 11.13 & 37.12 \\
$\mathrm{Bi}$ & 11.14 & 19.30 & 16.16 & 76.72 & & 11.12 & 36.69 \\
$\mathrm{~Pa}$ & 11.16 & 19.32 & 16.09 & 76.60 & & 11.15 & 36.45 \\
$\mathrm{Ca}$ & 11.38 & 19.71 & 16.37 & 76.49 & & 11.30 & 36.81 \\
$\mathrm{Th}$ & 11.32 & 19.59 & 16.21 & 76.55 & & 11.29 & 36.65 \\
$\mathrm{~K}$ & 11.67 & 20.20 & 16.52 & 76.64 & & 11.55 & 37.48 \\
$\mathrm{Sr}$ & 11.50 & 19.96 & 16.50 & 76.41 & & 11.46 & 37.19
\end{tabular}


Table 5: DFT relaxed lattice parameters for the $\mathrm{Mg}-\mathrm{X}^{\mathrm{L}}-\mathrm{Cu}$ LPSO structures, in $\AA$.

\begin{tabular}{lccccccc}
\hline \hline & \multicolumn{9}{c}{$18 \mathrm{R}-\mathrm{i}$} & & \multicolumn{2}{c}{$14 \mathrm{H}-\mathrm{i}$} \\
\cline { 2 - 4 } $\mathrm{X}^{\mathrm{L}}$ & $\mathrm{a}$ & $\mathrm{b}$ & $\mathrm{c}$ & $\beta\left[^{\circ}\right]$ & & $\mathrm{a}$ & $\mathrm{c}$ \\
\hline $\mathrm{Sc}$ & 10.94 & 18.96 & 15.77 & 76.55 & & 10.96 & 35.80 \\
$\mathrm{Y}$ & 11.08 & 19.22 & 16.03 & 76.55 & & 11.09 & 36.25 \\
$\mathrm{La}$ & 11.23 & 19.49 & 16.23 & 76.35 & & 11.25 & 36.72 \\
$\mathrm{Ce}$ & 11.22 & 19.49 & 16.23 & 76.36 & & 11.22 & 36.64 \\
$\mathrm{Pr}$ & 11.19 & 19.42 & 16.18 & 76.39 & & 11.20 & 36.58 \\
$\mathrm{Nd}$ & 11.17 & 19.39 & 16.16 & 76.43 & & 11.17 & 36.49 \\
$\mathrm{Pm}$ & 11.15 & 19.35 & 16.13 & 76.47 & & 11.71 & 38.26 \\
$\mathrm{Sm}$ & 11.13 & 19.32 & 16.11 & 76.48 & & 11.15 & 36.43 \\
$\mathrm{Eu}$ & 11.22 & 19.46 & 16.28 & 76.53 & & 11.20 & 36.87 \\
$\mathrm{Gd}$ & 11.09 & 19.25 & 16.06 & 76.52 & & 11.11 & 36.32 \\
$\mathrm{~Tb}$ & 11.08 & 19.22 & 16.04 & 76.53 & & 11.10 & 36.30 \\
$\mathrm{Dy}$ & 11.08 & 19.21 & 16.03 & 76.56 & & 11.09 & 36.26 \\
$\mathrm{Ho}$ & 11.06 & 19.18 & 16.00 & 76.56 & & 11.08 & 36.23 \\
$\mathrm{Er}$ & 11.05 & 19.15 & 15.98 & 76.57 & & 11.07 & 36.21 \\
$\mathrm{Tm}$ & 11.03 & 19.14 & 15.96 & 76.58 & & 11.06 & 36.17 \\
$\mathrm{Yb}$ & 11.13 & 19.31 & 16.19 & 76.60 & & 11.12 & 36.69 \\
$\mathrm{Lu}$ & 11.02 & 19.10 & 15.93 & 76.55 & & 11.04 & 36.12 \\
\hline $\mathrm{Tl}$ & 10.93 & 18.96 & 15.94 & 76.70 & & 10.98 & 36.14 \\
$\mathrm{Sb}$ & 10.94 & 18.98 & 15.86 & 76.62 & & 10.96 & 36.01 \\
$\mathrm{~Pb}$ & 10.97 & 19.01 & 16.05 & 76.94 & & 10.99 & 36.43 \\
$\mathrm{Na}$ & 11.04 & 19.11 & 16.00 & 76.67 & & 11.03 & 36.41 \\
$\mathrm{Te}$ & 11.00 & 19.04 & 16.13 & 76.74 & & 11.01 & 36.59 \\
$\mathrm{Bi}$ & 11.00 & 19.07 & 16.03 & 76.70 & & 11.02 & 36.38 \\
$\mathrm{~Pa}$ & 11.03 & 19.10 & 15.91 & 76.51 & & 11.04 & 36.12 \\
$\mathrm{Ca}$ & 11.17 & 19.37 & 16.23 & 76.60 & & 11.14 & 36.70 \\
$\mathrm{Th}$ & 11.16 & 19.34 & 16.08 & 76.47 & & 11.15 & 36.37 \\
$\mathrm{~K}$ & 11.39 & 19.72 & 16.60 & 76.71 & & 11.33 & 37.63 \\
$\mathrm{Sr}$ & 11.31 & 19.61 & 16.40 & 76.56 & & 11.29 & 37.13
\end{tabular}


Table 6: DFT relaxed lattice parameters for the $\mathrm{Mg}-\mathrm{X}^{\mathrm{L}}$-Co LPSO structures, in $\AA$.

\begin{tabular}{lccccccc}
\hline \hline & \multicolumn{9}{c}{$18 \mathrm{R}-\mathrm{i}$} & & \multicolumn{2}{c}{$14 \mathrm{H}-\mathrm{i}$} \\
\cline { 2 - 4 } $\mathrm{X}^{\mathrm{L}}$ & $\mathrm{a}$ & $\mathrm{b}$ & $\mathrm{c}$ & $\beta\left[^{\circ}\right]$ & & $\mathrm{a}$ & $\mathrm{c}$ \\
\hline $\mathrm{Sc}$ & 10.91 & 18.91 & 15.73 & 76.60 & & 10.94 & 35.78 \\
$\mathrm{Y}$ & 11.03 & 19.12 & 15.96 & 76.61 & & 11.03 & 36.25 \\
$\mathrm{La}$ & 11.16 & 19.31 & 16.14 & 76.57 & & 11.14 & 36.55 \\
$\mathrm{Ce}$ & 11.15 & 19.31 & 16.15 & 76.57 & & 11.14 & 36.58 \\
$\mathrm{Pr}$ & 11.12 & 19.26 & 16.10 & 76.58 & & 11.12 & 36.50 \\
$\mathrm{Nd}$ & 11.12 & 19.26 & 16.09 & 76.57 & & 11.11 & 36.48 \\
$\mathrm{Pm}$ & 11.10 & 19.22 & 16.05 & 76.59 & & 11.09 & 36.42 \\
$\mathrm{Sm}$ & 11.06 & 19.17 & 16.01 & 76.58 & & 11.07 & 36.35 \\
$\mathrm{Eu}$ & 11.02 & 19.08 & 16.04 & 76.76 & & 11.11 & 36.71 \\
$\mathrm{Gd}$ & 11.06 & 19.17 & 16.00 & 76.59 & & 11.05 & 36.27 \\
$\mathrm{~Tb}$ & 11.03 & 19.11 & 15.95 & 76.58 & & 11.03 & 36.24 \\
$\mathrm{Dy}$ & 11.02 & 19.10 & 15.94 & 76.58 & & 11.02 & 36.21 \\
$\mathrm{Ho}$ & 11.01 & 19.09 & 15.92 & 76.58 & & 11.02 & 36.19 \\
$\mathrm{Er}$ & 11.00 & 19.08 & 15.91 & 76.59 & & 11.01 & 36.17 \\
$\mathrm{Tm}$ & 10.99 & 19.05 & 15.88 & 76.58 & & 11.00 & 36.13 \\
$\mathrm{Yb}$ & 11.06 & 19.15 & 16.07 & 76.70 & & 11.05 & 36.47 \\
$\mathrm{Lu}$ & 10.97 & 19.02 & 15.86 & 76.60 & & 10.98 & 36.07 \\
\hline $\mathrm{Tl}$ & 10.84 & 18.80 & 15.77 & 76.74 & & 10.87 & 35.93 \\
$\mathrm{Sb}$ & 10.80 & 18.75 & 15.88 & 76.96 & & 10.86 & 36.14 \\
$\mathrm{~Pb}$ & 10.85 & 18.82 & 15.94 & 77.09 & & 10.88 & 36.32 \\
$\mathrm{Na}$ & 10.96 & 18.99 & 15.85 & 76.68 & & 10.98 & 36.09 \\
$\mathrm{Te}$ & 10.87 & 18.84 & 15.93 & 76.84 & & 10.93 & 36.13 \\
$\mathrm{Bi}$ & 10.87 & 18.86 & 15.99 & 77.02 & & 10.92 & 36.40 \\
$\mathrm{~Pa}$ & 11.01 & 19.05 & 15.85 & 76.45 & & 11.01 & 36.00 \\
$\mathrm{Ca}$ & 11.08 & 19.18 & 16.11 & 76.74 & & 11.07 & 36.52 \\
$\mathrm{Th}$ & 11.12 & 19.26 & 16.02 & 76.41 & & 11.11 & 36.31 \\
$\mathrm{~K}$ & 11.33 & 19.63 & 16.58 & 76.82 & & 11.28 & 37.49 \\
$\mathrm{Sr}$ & 11.25 & 19.44 & 16.38 & 76.84 & & 11.20 & 37.03
\end{tabular}


Table 7: DFT relaxed lattice parameters for the $\mathrm{Mg}-\mathrm{X}^{\mathrm{L}}-\mathrm{Ni}$ LPSO structures, in $\AA$.

\begin{tabular}{lccccccc}
\hline \hline & \multicolumn{9}{c}{$18 \mathrm{R}-\mathrm{i}$} & & \multicolumn{2}{c}{$14 \mathrm{H}-\mathrm{i}$} \\
\cline { 2 - 4 } $\mathrm{X}^{\mathrm{L}}$ & $\mathrm{a}$ & $\mathrm{b}$ & $\mathrm{c}$ & $\beta\left[^{\circ}\right]$ & & $\mathrm{a}$ & $\mathrm{c}$ \\
\hline $\mathrm{Sc}$ & 10.94 & 18.94 & 15.73 & 76.63 & & 10.94 & 35.75 \\
$\mathrm{Y}$ & 11.04 & 19.14 & 15.95 & 76.56 & & 11.06 & 36.22 \\
$\mathrm{La}$ & 11.19 & 19.39 & 16.15 & 76.40 & & 11.18 & 36.58 \\
$\mathrm{Ce}$ & 11.18 & 19.38 & 16.14 & 76.40 & & 11.17 & 36.53 \\
$\mathrm{Pr}$ & 11.15 & 19.33 & 16.10 & 76.40 & & 11.15 & 36.47 \\
$\mathrm{Nd}$ & 11.14 & 19.32 & 16.09 & 76.42 & & 11.13 & 36.44 \\
$\mathrm{Pm}$ & 11.11 & 19.26 & 16.05 & 76.44 & & 11.11 & 36.37 \\
$\mathrm{Sm}$ & 11.09 & 19.23 & 16.02 & 76.46 & & 11.09 & 36.33 \\
$\mathrm{Eu}$ & 11.16 & 19.31 & 16.17 & 76.69 & & 11.69 & 38.55 \\
$\mathrm{Gd}$ & 11.07 & 19.19 & 15.99 & 76.50 & & 11.07 & 36.26 \\
$\mathrm{~Tb}$ & 11.06 & 19.17 & 15.97 & 76.52 & & 11.06 & 36.22 \\
$\mathrm{Dy}$ & 11.04 & 19.14 & 15.95 & 76.54 & & 11.05 & 36.19 \\
$\mathrm{Ho}$ & 11.03 & 19.12 & 15.93 & 76.55 & & 11.03 & 36.15 \\
$\mathrm{Er}$ & 11.02 & 19.10 & 15.91 & 76.57 & & 11.03 & 36.15 \\
$\mathrm{Tm}$ & 11.01 & 19.09 & 15.90 & 76.59 & & 11.02 & 36.11 \\
$\mathrm{Yb}$ & 11.09 & 19.19 & 16.10 & 76.69 & & 11.07 & 36.57 \\
$\mathrm{Lu}$ & 10.99 & 19.05 & 15.86 & 76.61 & & 11.01 & 36.08 \\
\hline $\mathrm{Tl}$ & 10.85 & 18.80 & 15.87 & 76.78 & & 10.88 & 36.08 \\
$\mathrm{Sb}$ & 10.82 & 18.76 & 15.90 & 76.91 & & 10.87 & 36.11 \\
$\mathrm{~Pb}$ & 10.91 & 18.93 & 15.94 & 76.84 & & 10.94 & 36.31 \\
$\mathrm{Na}$ & 11.01 & 19.04 & 15.89 & 76.91 & & 11.00 & 36.25 \\
$\mathrm{Te}$ & 10.88 & 18.85 & 16.00 & 77.40 & & 10.92 & 36.45 \\
$\mathrm{Bi}$ & 10.90 & 18.89 & 16.04 & 76.93 & & 10.93 & 36.37 \\
$\mathrm{~Pa}$ & 11.01 & 19.05 & 15.85 & 76.46 & & 11.01 & 36.03 \\
$\mathrm{Ca}$ & 11.09 & 19.20 & 16.09 & 76.69 & & 11.08 & 36.59 \\
$\mathrm{Th}$ & 11.13 & 19.29 & 16.02 & 76.39 & & 11.12 & 36.26 \\
$\mathrm{~K}$ & 11.35 & 19.64 & 16.55 & 76.83 & & 11.31 & 37.50 \\
$\mathrm{Sr}$ & 11.27 & 19.48 & 16.35 & 76.70 & & 11.22 & 37.05 \\
& & & & & &
\end{tabular}


Table 8: Formation energies and stabilities for the Mg-X ${ }^{\mathrm{L}}$-Zn LPSO structures, in meV/atom. The stable convex hull compounds is given in order of decreasing phase fraction. The number for ICSD compound or the Strukturbericht designation for the simple ordered compounds is given in parentheses. The compounds are the same for both the $18 \mathrm{R}-\mathrm{i} \mathrm{Mg}_{59} \mathrm{X}_{8}^{\mathrm{L}} \mathrm{Zn}_{6}$ and $14 \mathrm{H}-\mathrm{i} \mathrm{Mg}_{71} \mathrm{X}_{8}^{\mathrm{L}} \mathrm{Zn}_{6}$ compositions, unless indicated otherwise by a footnote. A negative stability indicates the LPSO structure is more stable than the convex hull phases.

\begin{tabular}{|c|c|c|c|c|c|}
\hline \multirow[b]{2}{*}{$\mathrm{X}^{\mathrm{L}}$} & \multicolumn{2}{|c|}{$18 \mathrm{R}-\mathrm{i}$} & \multicolumn{2}{|c|}{$14 \mathrm{H}-\mathrm{i}$} & \multirow[b]{2}{*}{ Convex Hull Phases } \\
\hline & $\Delta \mathrm{E}_{\mathrm{F}}$ & $\Delta \mathrm{E}_{\mathrm{stab}}$ & $\Delta \mathrm{E}_{\mathrm{F}}$ & $\Delta \mathrm{E}_{\text {stab }}$ & \\
\hline $\mathrm{Sc}$ & -77 & -4 & -66 & -3 & $\mathrm{Mg}(\mathrm{A} 3 / \mathrm{HCP}), \mathrm{ScZn}(\mathrm{B} 2), \mathrm{Mg}_{3} \mathrm{Sc}\left(\mathrm{D} 0_{19}\right)$ \\
\hline $\mathrm{Y}$ & -98 & -13 & -85 & -12 & $\mathrm{Mg}(\mathrm{A} 3 / \mathrm{HCP}), \mathrm{MgYZn}(160907), \mathrm{Mg}_{3} \mathrm{Y}\left(\mathrm{D}_{3}\right)$ \\
\hline $\mathrm{La}$ & -86 & 23 & -74 & 20 & $\mathrm{Mg}_{12} \mathrm{La}(168466), \mathrm{MgLaZn}_{2}$ (Heusler), $\mathrm{Mg}(\mathrm{A} 3 / \mathrm{HCP})^{a}$ \\
\hline $\mathrm{Ce}$ & -88 & 16 & -76 & 14 & $\mathrm{Mg}_{12} \mathrm{Ce}(621495), \mathrm{MgCeZn}_{2}$ (Heusler), $\mathrm{Mg}(\mathrm{A} 3 / \mathrm{HCP})^{b}$ \\
\hline $\operatorname{Pr}$ & -91 & 10 & -78 & 9 & $\mathrm{Mg}_{12} \operatorname{Pr}(104856), \mathrm{MgPrZn}_{2}$ (Heusler), $\mathrm{Mg}(\mathrm{A} 3 / \mathrm{HCP})^{c}$ \\
\hline $\mathrm{Nd}$ & -92 & 6 & -79 & 5 & $\mathrm{Mg}_{41} \mathrm{Nd}_{5}(642680), \mathrm{Mg}(\mathrm{A} 3 / \mathrm{HCP}), \mathrm{MgNdZn}_{2}$ (Heusler) \\
\hline $\mathrm{Pm}$ & -93 & -2 & -81 & -3 & $\mathrm{Mg}(\mathrm{A} 3 / \mathrm{HCP}), \mathrm{Mg}_{3} \mathrm{Pm}\left(\mathrm{DO}_{22}\right), \mathrm{MgPmZn}_{2}$ (Heusler) \\
\hline $\mathrm{Sm}$ & -93 & -2 & -80 & -2 & $\mathrm{Mg}_{41} \mathrm{Sm}_{5}(642842), \mathrm{Mg}(\mathrm{A} 3 / \mathrm{HCP}), \mathrm{MgSmZn}_{2}$ (Heusler) \\
\hline $\mathrm{Eu}$ & -79 & 4 & -67 & 4 & $\mathrm{Mg}(\mathrm{A} 3 / \mathrm{HCP}), \mathrm{Mg}_{2} \mathrm{Eu}(412689), \mathrm{MgEuZn}_{2}$ (Heusler) \\
\hline $\mathrm{Gd}$ & -92 & -8 & -80 & -8 & $\mathrm{Mg}(\mathrm{A} 3 / \mathrm{HCP}), \mathrm{Mg}_{3} \mathrm{Gd}\left(\mathrm{DO}_{3}\right), \mathrm{MgGdZn}_{2}$ (Heusler) \\
\hline $\mathrm{Tb}$ & -91 & -10 & -79 & -9 & $\mathrm{Mg}(\mathrm{A} 3 / \mathrm{HCP}), \mathrm{Mg}_{3} \mathrm{~Tb}\left(\mathrm{D0}_{3}\right), \mathrm{MgTbZn}_{2}$ (Heusler) \\
\hline Dy & -90 & -12 & -78 & -11 & $\mathrm{Mg}(\mathrm{A} 3 / \mathrm{HCP}), \mathrm{Mg}_{3} \mathrm{Dy}\left(\mathrm{DO}_{3}\right), \mathrm{MgDyZn}_{2}$ (Heusler) \\
\hline Но & -88 & -13 & -76 & -11 & $\mathrm{Mg}(\mathrm{A} 3 / \mathrm{HCP}), \mathrm{Mg}_{3} \mathrm{Ho}\left(\mathrm{D0}_{3}\right), \mathrm{MgHoZn}_{2}$ (Heusler) \\
\hline Er & -86 & -13 & -74 & -11 & $\mathrm{Mg}(\mathrm{A} 3 / \mathrm{HCP}), \mathrm{Mg}_{24} \operatorname{Er}_{5}(109136), \mathrm{MgErZn}_{2}$ (Heusler) \\
\hline $\mathrm{Tm}$ & -83 & -15 & -72 & -14 & $\mathrm{Mg}(\mathrm{A} 3 / \mathrm{HCP}), \mathrm{Mg}_{3} \mathrm{Tm}\left(\mathrm{D0}_{3}\right), \mathrm{MgTmZn}_{2}$ (Heusler) \\
\hline $\mathrm{Yb}$ & -70 & 1 & -60 & 1 & $\mathrm{Mg}(\mathrm{A} 3 / \mathrm{HCP}), \mathrm{Mg}_{2} \mathrm{Yb}(104895), \mathrm{YbZn}_{2}(106234)$ \\
\hline $\mathrm{Lu}$ & -77 & -12 & -67 & -11 & $\mathrm{Mg}(\mathrm{A} 3 / \mathrm{HCP}), \operatorname{LuZn}(\mathrm{B} 2), \mathrm{Mg}_{24} \mathrm{Lu}_{5}(642418)$ \\
\hline $\mathrm{Tl}$ & -6 & 38 & -5 & 33 & $\mathrm{Mg}(\mathrm{A} 3 / \mathrm{HCP}), \mathrm{Mg}_{3} \mathrm{Tl}\left(\mathrm{D} 0_{19}\right), \mathrm{Mg}_{21} \mathrm{Zn}_{25}(240047)$ \\
\hline $\mathrm{Sb}$ & -35 & 86 & -30 & 74 & $\mathrm{Mg}(\mathrm{A} 3 / \mathrm{HCP}), \mathrm{Mg}_{3} \mathrm{Sb}_{2}(2142), \mathrm{Mg}_{21} \mathrm{Zn}_{25}(240047)$ \\
\hline $\mathrm{Pb}$ & -13 & 40 & -10 & 36 & $\mathrm{Mg}(\mathrm{A} 3 / \mathrm{HCP}), \mathrm{Mg}_{3} \mathrm{~Pb}\left(\mathrm{~L}_{2}\right), \mathrm{Mg}_{21} \mathrm{Zn}_{25}(240047)$ \\
\hline $\mathrm{Na}$ & 17 & 36 & 14 & 31 & $\mathrm{Mg}(\mathrm{A} 3 / \mathrm{HCP}), \mathrm{Mg}_{21} \mathrm{Zn}_{25}(240047), \mathrm{Na}(\mathrm{C} 19)$ \\
\hline $\mathrm{Te}$ & -52 & 165 & -45 & 141 & $\mathrm{Mg}(\mathrm{A} 3 / \mathrm{HCP}), \operatorname{MgTe}(52363), \mathrm{Mg}_{21} \mathrm{Zn}_{25}(240047)$ \\
\hline $\mathrm{Bi}$ & -27 & 58 & -23 & 50 & $\mathrm{Mg}(\mathrm{A} 3 / \mathrm{HCP}), \mathrm{Mg}_{3} \mathrm{Bi}_{2}(659569), \mathrm{Mg}_{21} \mathrm{Zn}_{25}(240047)$ \\
\hline $\mathrm{Pa}$ & 66 & 85 & 56 & 73 & $\mathrm{Mg}(\mathrm{A} 3 / \mathrm{HCP}), \mathrm{Mg}_{21} \mathrm{Zn}_{25}(240047), \mathrm{Pa}(\mathrm{A} 1 / \mathrm{FCC})$ \\
\hline $\mathrm{Ca}$ & -71 & -3 & -60 & -2 & $\mathrm{Mg}(\mathrm{A} 3 / \mathrm{HCP}), \mathrm{CaMg}_{2}(165564), \mathrm{CaZn}_{2}(58945)$ \\
\hline Th & -49 & -11 & -42 & -9 & $\mathrm{Mg}(\mathrm{A} 3 / \mathrm{HCP}), \operatorname{Th}_{2} \mathrm{Zn}(653254), \mathrm{MgThZn}_{2}$ (Heusler) \\
\hline $\mathrm{K}$ & 75 & 94 & 67 & 84 & $\mathrm{Mg}(\mathrm{A} 3 / \mathrm{HCP}), \mathrm{Mg}_{21} \mathrm{Zn}_{25}(240047), \mathrm{K}(\mathrm{A} 2 / \mathrm{BCC})$ \\
\hline $\mathrm{Sr}$ & -43 & 19 & -37 & 16 & $\mathrm{Mg}_{23} \mathrm{Sr}_{6}(104876), \mathrm{Mg}(\mathrm{A} 3 / \mathrm{HCP}), \mathrm{Mg}_{21} \mathrm{Zn}_{25}(240047)$ \\
\hline
\end{tabular}


Table 9: Formation energies and stabilities for the $\mathrm{Mg}-\mathrm{X}^{\mathrm{L}}-\mathrm{Al}$ LPSO structures, in meV/atom. The stable convex hull compounds is given in order of decreasing phase fraction. The number for ICSD compound or the Strukturbericht designation for the simple ordered compounds is given in parentheses. The compounds are the same for both the $18 \mathrm{R}-\mathrm{i} \mathrm{Mg}_{59} \mathrm{X}_{8}^{\mathrm{L}} \mathrm{Al}_{6}$ and $14 \mathrm{H}-\mathrm{i} \mathrm{Mg}_{71} \mathrm{X}_{8}^{\mathrm{L}} \mathrm{Al}_{6}$ compositions, unless indicated otherwise by a footnote. A negative stability indicates the LPSO structure is more stable than the convex hull phases.

\begin{tabular}{|c|c|c|c|c|c|}
\hline \multirow[b]{2}{*}{$\mathrm{X}^{\mathrm{L}}$} & \multicolumn{2}{|c|}{$18 \mathrm{R}-\mathrm{i}$} & \multicolumn{2}{|c|}{$14 \mathrm{H}-\mathrm{i}$} & \multirow[b]{2}{*}{ Convex Hull Phases } \\
\hline & $\Delta \mathrm{E}_{\mathrm{F}}$ & $\Delta \mathrm{E}_{\text {stab }}$ & $\Delta \mathrm{E}_{\mathrm{F}}$ & $\Delta \mathrm{E}_{\mathrm{stab}}$ & \\
\hline Sc & -76 & 10 & -66 & 7 & $\mathrm{Mg}(\mathrm{A} 3 / \mathrm{HCP}), \mathrm{AlSc}(\mathrm{B} 2), \mathrm{MgAlSc}_{2}$ (Heusler) \\
\hline Y & -101 & -8 & -87 & -7 & $\mathrm{Mg}(\mathrm{A} 3 / \mathrm{HCP}), \mathrm{MgAlY}(160908), \mathrm{Mg}_{3} \mathrm{Y}\left(\mathrm{D0}_{3}\right)$ \\
\hline La & -93 & 22 & -78 & 21 & $\mathrm{Mg}_{12} \mathrm{La}(168466), \mathrm{Mg}(\mathrm{A} 3 / \mathrm{HCP}), \mathrm{Al}_{2} \mathrm{La}(57933)^{a}$ \\
\hline $\mathrm{Ce}$ & -96 & 12 & -81 & 12 & $\mathrm{Mg}_{12} \mathrm{Ce}(621495), \mathrm{Mg}(\mathrm{A} 3 / \mathrm{HCP}), \mathrm{Al}_{2} \mathrm{Ce}(57555)^{b}$ \\
\hline $\operatorname{Pr}$ & -98 & 8 & -84 & 7 & $\mathrm{Mg}_{12} \operatorname{Pr}(104856), \mathrm{Mg}(\mathrm{A} 3 / \mathrm{HCP}), \mathrm{Al}_{2} \operatorname{Pr}(150504)^{c}$ \\
\hline $\mathrm{Nd}$ & -100 & 2 & -85 & 3 & $\mathrm{Mg}_{41} \mathrm{Nd}_{5}(642680), \mathrm{Mg}(\mathrm{A} 3 / \mathrm{HCP}), \mathrm{Al}_{2} \mathrm{Nd}(58027)$ \\
\hline $\mathrm{Pm}$ & -101 & -13 & -86 & -10 & $\mathrm{Mg}(\mathrm{A} 3 / \mathrm{HCP}), \mathrm{Mg}_{3} \mathrm{Pm}\left(\mathrm{D0}_{22}\right), \mathrm{Al}_{3} \mathrm{Pm}\left(\mathrm{D}_{19}\right)$ \\
\hline $\mathrm{Sm}$ & -100 & -3 & -85 & -2 & $\mathrm{Mg}_{41} \mathrm{Sm}_{5}(642842), \mathrm{Mg}(\mathrm{A} 3 / \mathrm{HCP}), \mathrm{Al}_{2} \mathrm{Sm}(58161)$ \\
\hline $\mathrm{Eu}$ & -58 & 24 & -49 & 21 & $\mathrm{Mg}(\mathrm{A} 3 / \mathrm{HCP}), \mathrm{Mg}_{2} \mathrm{Eu}(412689), \mathrm{Al}_{2} \mathrm{Eu}(57783)$ \\
\hline $\mathrm{Gd}$ & -98 & -8 & -84 & -7 & $\mathrm{Mg}(\mathrm{A} 3 / \mathrm{HCP}), \mathrm{Mg}_{3} \mathrm{Gd}\left(\mathrm{D0}_{3}\right), \mathrm{Al}_{2} \mathrm{Gd}(57868)$ \\
\hline $\mathrm{Tb}$ & -96 & -8 & -82 & -7 & $\mathrm{Mg}(\mathrm{A} 3 / \mathrm{HCP}), \mathrm{Mg}_{3} \mathrm{~Tb}\left(\mathrm{D0}_{3}\right), \mathrm{Al}_{2} \mathrm{~Tb}(58174)$ \\
\hline Dy & -93 & -8 & -80 & -7 & $\mathrm{Mg}(\mathrm{A} 3 / \mathrm{HCP}), \mathrm{Mg}_{3} \mathrm{Dy}\left(\mathrm{DO}_{3}\right), \mathrm{Al}_{2} \mathrm{Dy}(107648)$ \\
\hline Но & -91 & -9 & -78 & -8 & $\mathrm{Mg}(\mathrm{A} 3 / \mathrm{HCP}), \mathrm{Mg}_{3} \mathrm{Ho}\left(\mathrm{D0}_{3}\right), \mathrm{Al}_{2} \mathrm{Ho}(57911)$ \\
\hline Er & -87 & -7 & -75 & -7 & $\mathrm{Mg}(\mathrm{A} 3 / \mathrm{HCP}), \mathrm{Mg}_{24} \operatorname{Er}_{5}(109136), \mathrm{Al}_{2} \operatorname{Er}(57764)$ \\
\hline $\mathrm{Tm}$ & -82 & -7 & -71 & -7 & $\mathrm{Mg}(\mathrm{A} 3 / \mathrm{HCP}), \mathrm{Mg}_{3} \operatorname{Tm}\left(\mathrm{D0}_{3}\right), \mathrm{Al}_{2} \operatorname{Tm}(58192)$ \\
\hline $\mathrm{Yb}$ & -47 & 22 & -40 & 19 & $\mathrm{Mg}(\mathrm{A} 3 / \mathrm{HCP}), \mathrm{Mg}_{2} \mathrm{Yb}(104895), \mathrm{Al}_{2} \mathrm{Yb}(58223)$ \\
\hline $\mathrm{Lu}$ & -75 & -4 & -65 & -4 & $\mathrm{Mg}(\mathrm{A} 3 / \mathrm{HCP}), \mathrm{Mg}_{24} \mathrm{Lu}_{5}(642418), \mathrm{Al}_{2} \mathrm{Lu}(57958)$ \\
\hline $\mathrm{Tl}$ & 25 & 54 & 21 & 46 & $\mathrm{Mg}(\mathrm{A} 3 / \mathrm{HCP}), \mathrm{Mg}_{3} \mathrm{Tl}\left(\mathrm{D}_{19}\right), \mathrm{Mg}_{17} \mathrm{Al}_{12}(23607)$ \\
\hline $\mathrm{Sb}$ & -5 & 102 & -4 & 88 & $\mathrm{Mg}(\mathrm{A} 3 / \mathrm{HCP}), \mathrm{Mg}_{3} \mathrm{Sb}_{2}(2142), \mathrm{Mg}_{17} \mathrm{Al}_{12}(23607)$ \\
\hline $\mathrm{Pb}$ & 17 & 56 & 15 & 48 & $\mathrm{Mg}(\mathrm{A} 3 / \mathrm{HCP}), \mathrm{Mg}_{3} \mathrm{~Pb}\left(\mathrm{L1}_{2}\right), \mathrm{Mg}_{17} \mathrm{Al}_{12}(23607)$ \\
\hline $\mathrm{Na}$ & 45 & 50 & 39 & 43 & $\mathrm{Mg}(\mathrm{A} 3 / \mathrm{HCP}), \mathrm{Mg}_{17} \mathrm{Al}_{12}(23607), \mathrm{Na}(\mathrm{C} 19)$ \\
\hline $\mathrm{Te}$ & -17 & 185 & -14 & 160 & $\operatorname{Mg}(\mathrm{A} 3 / \mathrm{HCP}), \operatorname{MgTe}(52363), \mathrm{Mg}_{17} \mathrm{Al}_{12}(23607)$ \\
\hline $\mathrm{Bi}$ & 3 & 73 & 3 & 63 & $\mathrm{Mg}(\mathrm{A} 3 / \mathrm{HCP}), \mathrm{Mg}_{3} \mathrm{Bi}_{2}(659569), \mathrm{Mg}_{17} \mathrm{Al}_{12}(23607)$ \\
\hline $\mathrm{Pa}$ & 53 & 85 & 45 & 72 & $\mathrm{Mg}(\mathrm{A} 3 / \mathrm{HCP}), \mathrm{AlPa}_{3}\left(\mathrm{D}_{22}\right), \mathrm{Al}_{3} \mathrm{~Pa}\left(\mathrm{D}_{19}\right)$ \\
\hline $\mathrm{Ca}$ & -55 & 16 & -47 & 14 & $\mathrm{Mg}(\mathrm{A} 3 / \mathrm{HCP}), \mathrm{CaMg}_{2}(165564), \mathrm{CaAl}_{2}(30213)$ \\
\hline Th & -55 & 2 & -47 & 2 & $\mathrm{Mg}(\mathrm{A} 3 / \mathrm{HCP}), \mathrm{AlTh}_{2}(58180), \mathrm{Al}_{2} \mathrm{Th}(15447)$ \\
\hline $\mathrm{K}$ & 104 & 109 & 92 & 96 & $\mathrm{Mg}(\mathrm{A} 3 / \mathrm{HCP}), \mathrm{Mg}_{17} \mathrm{Al}_{12}(23607), \mathrm{K}(\mathrm{A} 2 / \mathrm{BCC})$ \\
\hline $\mathrm{Sr}$ & -29 & 30 & -23 & 27 & $\mathrm{Mg}(\mathrm{A} 3 / \mathrm{HCP}), \mathrm{Mg}_{23} \mathrm{Sr}_{6}(104876), \mathrm{SrAl}_{2}(58166)$ \\
\hline
\end{tabular}

${ }^{a} 18 \mathrm{R}-\mathrm{i}: \mathrm{Mg}_{12} \mathrm{La}(168466), \mathrm{Al}_{2} \mathrm{La}(57933), \mathrm{Mg}_{3} \mathrm{La}\left(\mathrm{D0}_{3}\right)$

${ }^{b} 18 \mathrm{R}-\mathrm{i}: \mathrm{Mg}_{12} \mathrm{Ce}(621495), \mathrm{Al}_{2} \mathrm{Ce}(57555), \mathrm{Mg}_{41} \mathrm{Ce}_{5}(621487)$

${ }^{c} 18 \mathrm{R}-\mathrm{i}: \mathrm{Mg}_{12} \operatorname{Pr}(104856), \mathrm{Al}_{2} \operatorname{Pr}(150504), \mathrm{Mg}_{41} \operatorname{Pr}_{5}(642771)$ 
Table 10: Formation energies and stabilities for the $\mathrm{Mg}-\mathrm{X}^{\mathrm{L}}-\mathrm{Cu}$ LPSO structures, in meV/atom. The stable convex hull compounds is given in order of decreasing phase fraction. The number for ICSD compound or the Strukturbericht designation for the simple ordered compounds is given in parentheses. The compounds are the same for both the $18 \mathrm{R}-\mathrm{i} \mathrm{Mg}_{59} \mathrm{X}_{8}^{\mathrm{L}} \mathrm{Cu}_{6}$ and $14 \mathrm{H}-\mathrm{i} \mathrm{Mg}_{71} \mathrm{X}_{8}^{\mathrm{L}} \mathrm{Cu}_{6}$ compositions, unless indicated otherwise by a footnote. A negative stability indicates the LPSO structure is more stable than the convex hull phases.

\begin{tabular}{|c|c|c|c|c|c|}
\hline \multirow[b]{2}{*}{$\mathrm{X}^{\mathrm{L}}$} & \multicolumn{2}{|c|}{$18 \mathrm{R}-\mathrm{i}$} & \multicolumn{2}{|c|}{$14 \mathrm{H}-\mathrm{i}$} & \multirow[b]{2}{*}{ Convex Hull Phases } \\
\hline & $\Delta \mathrm{E}_{\mathrm{F}}$ & $\Delta \mathrm{E}_{\text {stab }}$ & $\Delta \mathrm{E}_{\mathrm{F}}$ & $\Delta \mathrm{E}_{\mathrm{stab}}$ & \\
\hline $\mathrm{Sc}$ & -67 & -11 & -58 & -10 & $\mathrm{Mg}(\mathrm{A} 3 / \mathrm{HCP}), \mathrm{CuSc}(\mathrm{B} 2), \mathrm{Mg}_{3} \mathrm{Sc}\left(\mathrm{D0}_{19}\right)$ \\
\hline $\mathrm{Y}$ & -84 & -7 & -73 & -7 & $\mathrm{Mg}(\mathrm{A} 3 / \mathrm{HCP}), \mathrm{Mg}_{4} \mathrm{CuY}(419475), \mathrm{Mg}_{3} \mathrm{Y}\left(\mathrm{D0}_{3}\right)$ \\
\hline La & -72 & 28 & -62 & 27 & $\mathrm{Mg}_{12} \mathrm{La}(168466), \mathrm{Mg}_{2} \mathrm{Cu}(659334), \mathrm{Mg}_{3} \mathrm{La}\left(\mathrm{D0}_{3}\right)$ \\
\hline $\mathrm{Ce}$ & -70 & 29 & -61 & 28 & $\mathrm{Mg}_{41} \mathrm{Ce}_{5}(621487), \mathrm{Mg}_{2} \mathrm{Cu}(659334), \mathrm{Mg}_{3} \mathrm{Ce}\left(\mathrm{DO}_{3}\right)$ \\
\hline $\operatorname{Pr}$ & -73 & 22 & -63 & 22 & $\mathrm{Mg}_{41} \operatorname{Pr}_{5}(642771), \mathrm{Mg}_{2} \mathrm{Cu}(659334), \mathrm{Mg}_{3} \operatorname{Pr}(104854)$ \\
\hline $\mathrm{Nd}$ & -75 & 16 & -65 & 16 & $\mathrm{Mg}_{41} \mathrm{Nd}_{5}(642680), \mathrm{Mg}_{2} \mathrm{Cu}(659334), \mathrm{Mg}_{3} \mathrm{Nd}\left(\mathrm{D}_{22}\right)$ \\
\hline $\mathrm{Pm}$ & -77 & 6 & -67 & 4 & $\mathrm{Mg}(\mathrm{A} 3 / \mathrm{HCP}), \mathrm{Mg}_{3} \mathrm{Pm}\left(\mathrm{DO}_{22}\right), \mathrm{Mg}_{2} \mathrm{Cu}(659334)$ \\
\hline $\mathrm{Sm}$ & -77 & 5 & -67 & 5 & $\mathrm{Mg}_{41} \mathrm{Sm}_{5}(642842), \mathrm{Mg}_{2} \mathrm{Cu}(659334), \mathrm{Mg}_{3} \mathrm{Sm}\left(\mathrm{DO}_{22}\right)$ \\
\hline $\mathrm{Eu}$ & -67 & 13 & -58 & 11 & $\mathrm{Mg}(\mathrm{A} 3 / \mathrm{HCP}), \mathrm{Mg}_{2} \mathrm{Eu}(412689), \mathrm{Mg}_{2} \mathrm{Cu}(659334)$ \\
\hline Gd & -79 & -7 & -69 & -7 & $\mathrm{Mg}(\mathrm{A} 3 / \mathrm{HCP}), \mathrm{Mg}_{3} \mathrm{Gd}\left(\mathrm{D0}_{3}\right), \mathrm{Mg}_{2} \mathrm{Cu}(659334)$ \\
\hline $\mathrm{Tb}$ & -79 & -6 & -69 & -7 & $\mathrm{Mg}(\mathrm{A} 3 / \mathrm{HCP}), \mathrm{Mg}_{4} \mathrm{CuTb}(418215), \mathrm{Mg}_{3} \mathrm{~Tb}\left(\mathrm{D0}_{3}\right)$ \\
\hline Dy & -79 & -15 & -69 & -14 & $\mathrm{Mg}(\mathrm{A} 3 / \mathrm{HCP}), \mathrm{Mg}_{3} \mathrm{Dy}\left(\mathrm{D0}_{3}\right), \mathrm{Mg}_{2} \mathrm{Cu}(659334)$ \\
\hline Но & -78 & -18 & -68 & -16 & $\mathrm{Mg}(\mathrm{A} 3 / \mathrm{HCP}), \mathrm{Mg}_{3} \mathrm{Ho}\left(\mathrm{D0}_{3}\right), \mathrm{Mg}_{2} \mathrm{Cu}(659334)$ \\
\hline Er & -78 & -20 & -68 & -18 & $\mathrm{Mg}_{24} \operatorname{Er}_{5}(109136), \mathrm{Mg}(\mathrm{A} 3 / \mathrm{HCP}), \mathrm{Mg}_{2} \mathrm{Cu}(659334)$ \\
\hline $\mathrm{Tm}$ & -76 & -21 & -66 & -19 & $\operatorname{Mg}(\mathrm{A} 3 / \mathrm{HCP}), \mathrm{CuTm}(\mathrm{B} 2), \mathrm{Mg}_{3} \operatorname{Tm}\left(\mathrm{D0}_{3}\right)$ \\
\hline Yb & -61 & 8 & -53 & 6 & $\mathrm{Mg}(\mathrm{A} 3 / \mathrm{HCP}), \mathrm{Mg}_{2} \mathrm{Yb}(104895), \mathrm{Mg}_{2} \mathrm{Cu}(659334)$ \\
\hline $\mathrm{Lu}$ & -73 & -16 & -64 & -15 & $\mathrm{Mg}(\mathrm{A} 3 / \mathrm{HCP}), \mathrm{CuLu}(\mathrm{B} 2), \mathrm{Mg}_{24} \mathrm{Lu}_{5}(642418)$ \\
\hline $\mathrm{Tl}$ & -3 & 53 & -2 & 46 & $\mathrm{Mg}(\mathrm{A} 3 / \mathrm{HCP}), \mathrm{Mg}_{3} \mathrm{Tl}\left(\mathrm{D} 0_{19}\right), \mathrm{Mg}_{2} \mathrm{Cu}(659334)$ \\
\hline $\mathrm{Sb}$ & -34 & 99 & -27 & 87 & $\mathrm{Mg}(\mathrm{A} 3 / \mathrm{HCP}), \mathrm{Mg}_{3} \mathrm{Sb}_{2}(2142), \mathrm{Mg}_{2} \mathrm{Cu}(659334)$ \\
\hline $\mathrm{Pb}$ & -12 & 53 & -11 & 45 & $\mathrm{Mg}(\mathrm{A} 3 / \mathrm{HCP}), \mathrm{Mg}_{3} \mathrm{~Pb}\left(\mathrm{~L}_{2}\right), \mathrm{Mg}_{2} \mathrm{Cu}(659334)$ \\
\hline $\mathrm{Na}$ & 34 & 65 & 29 & 56 & $\mathrm{Mg}(\mathrm{A} 3 / \mathrm{HCP}), \mathrm{Mg}_{2} \mathrm{Cu}(659334), \mathrm{Na}(\mathrm{C} 19)$ \\
\hline $\mathrm{Te}$ & -50 & 179 & -42 & 154 & $\mathrm{Mg}(\mathrm{A} 3 / \mathrm{HCP}), \mathrm{Mg}_{2} \mathrm{Cu}(659334), \mathrm{MgTe}(52363)$ \\
\hline $\mathrm{Bi}$ & -24 & 73 & -19 & 64 & $\mathrm{Mg}(\mathrm{A} 3 / \mathrm{HCP}), \mathrm{Mg}_{3} \mathrm{Bi}_{2}(659569), \mathrm{Mg}_{2} \mathrm{Cu}(659334)$ \\
\hline $\mathrm{Pa}$ & 67 & 98 & 56 & 83 & $\mathrm{Mg}(\mathrm{A} 3 / \mathrm{HCP}), \mathrm{Mg}_{2} \mathrm{Cu}(659334), \mathrm{Pa}(\mathrm{A} 1 / \mathrm{FCC})$ \\
\hline $\mathrm{Ca}$ & -57 & 19 & -49 & 16 & $\mathrm{Mg}(\mathrm{A} 3 / \mathrm{HCP}), \mathrm{CaMg}_{2}(165564), \mathrm{Mg}_{2} \mathrm{Cu}(659334)$ \\
\hline Th & -35 & -4 & -31 & -4 & $\mathrm{Mg}(\mathrm{A} 3 / \mathrm{HCP}), \mathrm{Mg}_{2} \mathrm{Cu}(659334), \operatorname{Th}(\mathrm{A} 1 / \mathrm{FCC})$ \\
\hline $\mathrm{K}$ & 89 & 120 & 79 & 106 & $\mathrm{Mg}(\mathrm{A} 3 / \mathrm{HCP}), \mathrm{Mg}_{2} \mathrm{Cu}(659334), \mathrm{K}(\mathrm{A} 2 / \mathrm{BCC})$ \\
\hline $\mathrm{Sr}$ & -28 & 45 & -22 & 41 & $\mathrm{Mg}_{23} \mathrm{Sr}_{6}(104876), \mathrm{Mg}(\mathrm{A} 3 / \mathrm{HCP}), \mathrm{Mg}_{2} \mathrm{Cu}(659334)$ \\
\hline
\end{tabular}


Table 11: Formation energies and stabilities for the $\mathrm{Mg}-\mathrm{X}^{\mathrm{L}}$-Co LPSO structures, in meV/atom. The stable convex hull compounds is given in order of decreasing phase fraction. The number for ICSD compound or the Strukturbericht designation for the simple ordered compounds is given in parentheses. The compounds are the same for both the $18 \mathrm{R}-\mathrm{i} \mathrm{Mg}_{59} \mathrm{X}_{8}^{\mathrm{L}} \mathrm{Co}_{6}$ and $14 \mathrm{H}-\mathrm{i} \mathrm{Mg}_{71} \mathrm{X}_{8}^{\mathrm{L}} \mathrm{Co}_{6}$ compositions, unless indicated otherwise by a footnote. A negative stability indicates the LPSO structure is more stable than the convex hull phases.

\begin{tabular}{|c|c|c|c|c|c|}
\hline \multirow[b]{2}{*}{$\mathrm{X}^{\mathrm{L}}$} & \multicolumn{2}{|c|}{$18 \mathrm{R}-\mathrm{i}$} & \multicolumn{2}{|c|}{$14 \mathrm{H}-\mathrm{i}$} & \multirow[b]{2}{*}{ Convex Hull Phases } \\
\hline & $\Delta \mathrm{E}_{\mathrm{F}}$ & $\Delta \mathrm{E}_{\text {stab }}$ & $\Delta \mathrm{E}_{\mathrm{F}}$ & $\Delta \mathrm{E}_{\mathrm{stab}}$ & \\
\hline Sc & -63 & 6 & -54 & 6 & $\mathrm{Mg}(\mathrm{A} 3 / \mathrm{HCP}), \mathrm{CoSc}(\mathrm{B} 2), \mathrm{Mg}_{3} \mathrm{Sc}\left(\mathrm{D}_{19}\right)$ \\
\hline Y & -61 & -12 & -53 & -11 & $\mathrm{Mg}(\mathrm{A} 3 / \mathrm{HCP}), \mathrm{Mg}_{3} \mathrm{Y}\left(\mathrm{D0}_{3}\right), \mathrm{Co}_{3} \mathrm{Y}(625559)$ \\
\hline $\mathrm{La}$ & -50 & 23 & -43 & 23 & $\mathrm{Mg}_{12} \mathrm{La}(168466), \mathrm{Mg}_{3} \mathrm{La}\left(\mathrm{D0}_{3}\right), \mathrm{Co}_{13} \mathrm{La}(656879)$ \\
\hline $\mathrm{Ce}$ & -37 & 36 & -33 & 33 & $\mathrm{Mg}_{41} \mathrm{Ce}_{5}(621487), \mathrm{Mg}_{12} \mathrm{Ce}(621495), \mathrm{Co}(\mathrm{A} 3 / \mathrm{HCP})^{a}$ \\
\hline $\operatorname{Pr}$ & -43 & 25 & -38 & 23 & $\mathrm{Mg}_{41} \operatorname{Pr}_{5}(642771), \mathrm{Mg}_{12} \operatorname{Pr}(104856), \mathrm{Co}(\mathrm{A} 3 / \mathrm{HCP})^{b}$ \\
\hline $\mathrm{Nd}$ & -47 & 16 & -42 & 13 & $\mathrm{Mg}_{41} \mathrm{Nd}_{5}(642680), \mathrm{Co}(\mathrm{A} 3 / \mathrm{HCP}), \mathrm{Mg}(\mathrm{A} 3 / \mathrm{HCP})^{c}$ \\
\hline $\mathrm{Pm}$ & -52 & 0 & -46 & -2 & $\mathrm{Mg}(\mathrm{A} 3 / \mathrm{HCP}), \mathrm{Mg}_{3} \mathrm{Pm}\left(\mathrm{D0}_{22}\right), \mathrm{Co}(\mathrm{A} 3 / \mathrm{HCP})$ \\
\hline $\mathrm{Sm}$ & -54 & 1 & -47 & 0 & $\mathrm{Mg}_{41} \mathrm{Sm}_{5}(642842), \mathrm{Mg}(\mathrm{A} 3 / \mathrm{HCP}), \mathrm{Co}_{17} \mathrm{Sm}_{2}(625233)^{d}$ \\
\hline $\mathrm{Eu}$ & 1 & 50 & 0 & 42 & $\mathrm{Mg}(\mathrm{A} 3 / \mathrm{HCP}), \mathrm{Mg}_{2} \mathrm{Eu}(412689), \mathrm{Co}(\mathrm{A} 3 / \mathrm{HCP})$ \\
\hline Gd & -59 & -13 & -52 & -13 & $\operatorname{Mg}(\mathrm{A} 3 / \mathrm{HCP}), \mathrm{Mg}_{3} \mathrm{Gd}\left(\mathrm{D0}_{3}\right), \mathrm{Co}_{17} \mathrm{Gd}_{2}(623333)$ \\
\hline $\mathrm{Tb}$ & -61 & -17 & -53 & -15 & $\mathrm{Mg}(\mathrm{A} 3 / \mathrm{HCP}), \mathrm{Mg}_{3} \mathrm{~Tb}\left(\mathrm{D}_{3}\right), \mathrm{Co}_{2} \mathrm{~Tb}(152587)$ \\
\hline Dy & -62 & -18 & -54 & -16 & $\mathrm{Mg}(\mathrm{A} 3 / \mathrm{HCP}), \mathrm{Mg}_{3} \mathrm{Dy}\left(\mathrm{D0}_{3}\right), \mathrm{Co}_{2} \mathrm{Dy}(163700)$ \\
\hline Ho & -62 & -18 & -55 & -17 & $\mathrm{Mg}(\mathrm{A} 3 / \mathrm{HCP}), \mathrm{Mg}_{3} \mathrm{Ho}\left(\mathrm{D}_{3}\right), \mathrm{Co}_{2} \mathrm{Ho}(108296)$ \\
\hline Er & -63 & -18 & -55 & -17 & $\mathrm{Mg}(\mathrm{A} 3 / \mathrm{HCP}), \mathrm{Mg}_{24} \operatorname{Er}_{5}(109136), \mathrm{Co}_{2} \operatorname{Er}(622773)$ \\
\hline Tm & -63 & -20 & -55 & -18 & $\operatorname{Mg}(\mathrm{A} 3 / \mathrm{HCP}), \mathrm{Mg}_{3} \operatorname{Tm}\left(\mathrm{D0}_{3}\right), \mathrm{Co}_{2} \operatorname{Tm}(625505)$ \\
\hline $\mathrm{Yb}$ & 3 & 41 & 2 & 35 & $\mathrm{Mg}(\mathrm{A} 3 / \mathrm{HCP}), \mathrm{Mg}_{2} \mathrm{Yb}(104895), \mathrm{Co}(\mathrm{A} 3 / \mathrm{HCP})$ \\
\hline $\mathrm{Lu}$ & -62 & -13 & -54 & -12 & $\operatorname{Mg}(\mathrm{A} 3 / \mathrm{HCP}), \mathrm{CoLu}(\mathrm{B} 2), \mathrm{CoLu}_{3}(624053)$ \\
\hline $\mathrm{Tl}$ & 48 & 72 & 40 & 61 & $\mathrm{Mg}(\mathrm{A} 3 / \mathrm{HCP}), \mathrm{Mg}_{3} \mathrm{Tl}\left(\mathrm{D0}_{19}\right), \mathrm{Co}(\mathrm{A} 3 / \mathrm{HCP})$ \\
\hline $\mathrm{Sb}$ & -24 & 78 & -21 & 67 & $\mathrm{Mg}(\mathrm{A} 3 / \mathrm{HCP}), \mathrm{Mg}_{3} \mathrm{Sb}_{2}(2142), \mathrm{Co}(\mathrm{A} 3 / \mathrm{HCP})$ \\
\hline $\mathrm{Pb}$ & 28 & 62 & 23 & 52 & $\mathrm{Mg}(\mathrm{A} 3 / \mathrm{HCP}), \mathrm{Mg}_{3} \mathrm{~Pb}\left(\mathrm{~L} 1_{2}\right), \mathrm{Co}(\mathrm{A} 3 / \mathrm{HCP})$ \\
\hline $\mathrm{Na}$ & 128 & 128 & 109 & 109 & $\mathrm{Mg}(\mathrm{A} 3 / \mathrm{HCP}), \mathrm{Na}(\mathrm{C} 19), \mathrm{Co}(\mathrm{A} 3 / \mathrm{HCP})$ \\
\hline $\mathrm{Te}$ & -18 & 180 & -15 & 155 & $\operatorname{Mg}(\mathrm{A} 3 / \mathrm{HCP}), \operatorname{MgTe}(52363), \mathrm{Co}(\mathrm{A} 3 / \mathrm{HCP})$ \\
\hline $\mathrm{Bi}$ & 2 & 67 & 2 & 58 & $\mathrm{Mg}(\mathrm{A} 3 / \mathrm{HCP}), \mathrm{Mg}_{3} \mathrm{Bi}_{2}(659569), \mathrm{Co}(\mathrm{A} 3 / \mathrm{HCP})$ \\
\hline $\mathrm{Pa}$ & -25 & 12 & -18 & 13 & $\mathrm{Mg}(\mathrm{A} 3 / \mathrm{HCP}), \mathrm{Co}_{3} \mathrm{~Pa}\left(\mathrm{~L}_{2}\right), \mathrm{Pa}(\mathrm{A} 1 / \mathrm{FCC})$ \\
\hline $\mathrm{Ca}$ & 14 & 59 & 11 & 49 & $\mathrm{Mg}(\mathrm{A} 3 / \mathrm{HCP}), \mathrm{CaMg}_{2}(165564), \mathrm{Co}(\mathrm{A} 3 / \mathrm{HCP})$ \\
\hline Th & -69 & -6 & -60 & -6 & $\operatorname{Mg}(\mathrm{A} 3 / \mathrm{HCP}), \mathrm{CoTh}(625442), \mathrm{Co}_{3} \mathrm{Th}_{7}(625455)$ \\
\hline $\mathrm{K}$ & 184 & 184 & 159 & 159 & $\mathrm{Mg}(\mathrm{A} 3 / \mathrm{HCP}), \mathrm{K}(\mathrm{A} 2 / \mathrm{BCC}), \mathrm{Co}(\mathrm{A} 3 / \mathrm{HCP})$ \\
\hline $\mathrm{Sr}$ & 49 & 91 & 41 & 77 & $\mathrm{Mg}(\mathrm{A} 3 / \mathrm{HCP}), \mathrm{Mg}_{23} \mathrm{Sr}_{6}(104876), \mathrm{Co}(\mathrm{A} 3 / \mathrm{HCP})$ \\
\hline
\end{tabular}


Table 12: Formation energies and stabilities for the $\mathrm{Mg}-\mathrm{X}^{\mathrm{L}}-\mathrm{Ni}$ LPSO structures, in meV/atom. The stable convex hull compounds is given in order of decreasing phase fraction. The number for ICSD compound or the Strukturbericht designation for the simple ordered compounds is given in parentheses. The compounds are the same for both the $18 \mathrm{R}-\mathrm{i} \mathrm{Mg}_{59} \mathrm{X}_{8}^{\mathrm{L}} \mathrm{Ni}_{6}$ and $14 \mathrm{H}-\mathrm{i} \mathrm{Mg}_{71} \mathrm{X}_{8}^{\mathrm{L}} \mathrm{Ni}_{6}$ compositions. A negative stability indicates the LPSO structure is more stable than the convex hull phases.

\begin{tabular}{|c|c|c|c|c|c|}
\hline \multirow[b]{2}{*}{$\mathrm{X}^{\mathrm{L}}$} & \multicolumn{2}{|c|}{$18 \mathrm{R}-\mathrm{i}$} & \multicolumn{2}{|c|}{$14 \mathrm{H}-\mathrm{i}$} & \multirow[b]{2}{*}{ Convex Hull Phases } \\
\hline & $\Delta \mathrm{E}_{\mathrm{F}}$ & $\Delta \mathrm{E}_{\text {stab }}$ & $\Delta \mathrm{E}_{\mathrm{F}}$ & $\Delta \mathrm{E}_{\mathrm{stab}}$ & \\
\hline Sc & -106 & -12 & -91 & -10 & $\mathrm{Mg}(\mathrm{A} 3 / \mathrm{HCP}), \mathrm{NiSc}(\mathrm{B} 2), \mathrm{Mg}_{3} \mathrm{Sc}\left(\mathrm{D0}_{19}\right)$ \\
\hline Y & -112 & -25 & -97 & -22 & $\mathrm{Mg}(\mathrm{A} 3 / \mathrm{HCP}), \mathrm{Mg}_{3} \mathrm{Y}\left(\mathrm{D0}_{3}\right), \mathrm{Mg}_{2} \mathrm{Ni}(30713)$ \\
\hline La & -98 & 18 & -85 & 18 & $\mathrm{Mg}_{12} \mathrm{La}(168466), \mathrm{Mg}_{2} \mathrm{Ni}(30713), \mathrm{Mg}_{3} \mathrm{La}\left(\mathrm{D0}_{3}\right)$ \\
\hline $\mathrm{Ce}$ & -90 & 25 & -78 & 25 & $\mathrm{Mg}_{41} \mathrm{Ce}_{5}(621487), \mathrm{Mg}_{2} \mathrm{Ni}(30713), \mathrm{Mg}_{3} \mathrm{Ce}\left(\mathrm{D}_{3}\right)$ \\
\hline $\operatorname{Pr}$ & -95 & 17 & -82 & 17 & $\mathrm{Mg}_{41} \operatorname{Pr}_{5}(642771), \mathrm{Mg}_{2} \mathrm{Ni}(30713), \mathrm{Mg}_{3} \operatorname{Pr}(104854)$ \\
\hline $\mathrm{Nd}$ & -99 & 8 & -85 & 10 & $\mathrm{Mg}_{41} \mathrm{Nd}_{5}(642680), \mathrm{Mg}_{2} \mathrm{Ni}(30713), \mathrm{Mg}_{3} \mathrm{Nd}\left(\mathrm{DO}_{22}\right)$ \\
\hline $\mathrm{Pm}$ & -102 & -3 & -88 & -3 & $\mathrm{Mg}(\mathrm{A} 3 / \mathrm{HCP}), \mathrm{Mg}_{3} \mathrm{Pm}\left(\mathrm{DO}_{22}\right), \mathrm{Mg}_{2} \mathrm{Ni}(30713)$ \\
\hline $\mathrm{Sm}$ & -104 & -6 & -90 & -4 & $\mathrm{Mg}_{41} \mathrm{Sm}_{5}(642842), \mathrm{Mg}_{2} \mathrm{Ni}(30713), \mathrm{Mg}_{3} \mathrm{Sm}\left(\mathrm{D0}_{22}\right)$ \\
\hline $\mathrm{Eu}$ & -71 & 25 & -62 & 21 & $\mathrm{Mg}(\mathrm{A} 3 / \mathrm{HCP}), \mathrm{Mg}_{2} \mathrm{Eu}(412689), \mathrm{Mg}_{2} \mathrm{Ni}(30713)$ \\
\hline Gd & -109 & -19 & -94 & -17 & $\mathrm{Mg}(\mathrm{A} 3 / \mathrm{HCP}), \mathrm{Mg}_{3} \mathrm{Gd}_{2} \mathrm{Ni}_{2}(421933), \mathrm{Mg}_{3} \mathrm{Gd}\left(\mathrm{D}_{3}\right)$ \\
\hline $\mathrm{Tb}$ & -110 & -18 & -95 & -16 & $\mathrm{Mg}(\mathrm{A} 3 / \mathrm{HCP}), \mathrm{Mg}_{3} \mathrm{Ni}_{2} \mathrm{~Tb}_{2}(240761), \mathrm{Mg}_{3} \mathrm{~Tb}\left(\mathrm{D0}_{3}\right)$ \\
\hline Dy & -111 & -27 & -96 & -24 & $\mathrm{Mg}(\mathrm{A} 3 / \mathrm{HCP}), \mathrm{DyNi}(109242), \mathrm{Mg}_{3} \mathrm{Dy}\left(\mathrm{D0}_{3}\right)$ \\
\hline Но & -112 & -27 & -96 & -23 & $\mathrm{Mg}(\mathrm{A} 3 / \mathrm{HCP}), \mathrm{HoNi}(106792), \mathrm{Mg}_{3} \mathrm{Ho}\left(\mathrm{D}_{3}\right)$ \\
\hline Er & -112 & -23 & -97 & -20 & $\operatorname{Mg}(\mathrm{A} 3 / \mathrm{HCP}), \operatorname{ErNi}(630842), \mathrm{Mg}_{24} \operatorname{Er}_{5}(109136)$ \\
\hline $\mathrm{Tm}$ & -111 & -22 & -96 & -19 & $\mathrm{Mg}(\mathrm{A} 3 / \mathrm{HCP}), \mathrm{NiTm}(105428), \mathrm{Mg}_{3} \operatorname{Tm}\left(\mathrm{D0}_{3}\right)$ \\
\hline $\mathrm{Yb}$ & -67 & 18 & -59 & 14 & $\mathrm{Mg}(\mathrm{A} 3 / \mathrm{HCP}), \mathrm{Mg}_{2} \mathrm{Yb}(104895), \mathrm{Mg}_{2} \mathrm{Ni}(30713)$ \\
\hline $\mathrm{Lu}$ & -110 & -16 & -95 & -15 & $\mathrm{Mg}(\mathrm{A} 3 / \mathrm{HCP}), \mathrm{LuNi}(642448), \mathrm{Mg}_{24} \mathrm{Lu}_{5}(642418)$ \\
\hline $\mathrm{Tl}$ & -13 & 59 & -11 & 51 & $\mathrm{Mg}(\mathrm{A} 3 / \mathrm{HCP}), \mathrm{Mg}_{3} \mathrm{Tl}\left(\mathrm{D} 0_{19}\right), \mathrm{Mg}_{2} \mathrm{Ni}(30713)$ \\
\hline $\mathrm{Sb}$ & -60 & 89 & -51 & 77 & $\mathrm{Mg}(\mathrm{A} 3 / \mathrm{HCP}), \mathrm{Mg}_{3} \mathrm{Sb}_{2}(2142), \mathrm{Mg}_{2} \mathrm{Ni}(30713)$ \\
\hline $\mathrm{Pb}$ & -30 & 51 & -26 & 44 & $\mathrm{Mg}(\mathrm{A} 3 / \mathrm{HCP}), \mathrm{Mg}_{3} \mathrm{~Pb}\left(\mathrm{~L}_{2}\right), \mathrm{Mg}_{2} \mathrm{Ni}(30713)$ \\
\hline $\mathrm{Na}$ & 46 & 93 & 38 & 79 & $\mathrm{Mg}(\mathrm{A} 3 / \mathrm{HCP}), \mathrm{Mg}_{2} \mathrm{Ni}(30713), \mathrm{Na}(\mathrm{C} 19)$ \\
\hline $\mathrm{Te}$ & -67 & 178 & -56 & 154 & $\mathrm{Mg}(\mathrm{A} 3 / \mathrm{HCP}), \mathrm{Mg}_{2} \mathrm{Ni}(30713), \mathrm{MgTe}(52363)$ \\
\hline $\mathrm{Bi}$ & -45 & 68 & -39 & 58 & $\mathrm{Mg}(\mathrm{A} 3 / \mathrm{HCP}), \mathrm{Mg}_{3} \mathrm{Bi}_{2}(659569), \mathrm{Mg}_{2} \mathrm{Ni}(30713)$ \\
\hline $\mathrm{Pa}$ & 9 & 56 & -10 & 31 & $\mathrm{Mg}(\mathrm{A} 3 / \mathrm{HCP}), \mathrm{Mg}_{2} \mathrm{Ni}(30713), \mathrm{Pa}(\mathrm{A} 1 / \mathrm{FCC})$ \\
\hline $\mathrm{Ca}$ & -58 & 34 & -52 & 27 & $\mathrm{Mg}(\mathrm{A} 3 / \mathrm{HCP}), \mathrm{CaMg}_{2}(165564), \mathrm{Mg}_{2} \mathrm{Ni}(30713)$ \\
\hline Th & -89 & -13 & -77 & -12 & $\operatorname{Mg}(\mathrm{A} 3 / \mathrm{HCP}), \mathrm{NiTh}(105403), \mathrm{Ni}_{3} \mathrm{Th}_{7}(105406)$ \\
\hline $\mathrm{K}$ & 99 & 146 & 85 & 126 & $\mathrm{Mg}(\mathrm{A} 3 / \mathrm{HCP}), \mathrm{Mg}_{2} \mathrm{Ni}(30713), \mathrm{K}(\mathrm{A} 2 / \mathrm{BCC})$ \\
\hline $\mathrm{Sr}$ & -26 & 64 & -23 & 54 & $\mathrm{Mg}_{23} \mathrm{Sr}_{6}(104876), \mathrm{Mg}(\mathrm{A} 3 / \mathrm{HCP}), \mathrm{Mg}_{2} \mathrm{Ni}(30713)$ \\
\hline
\end{tabular}




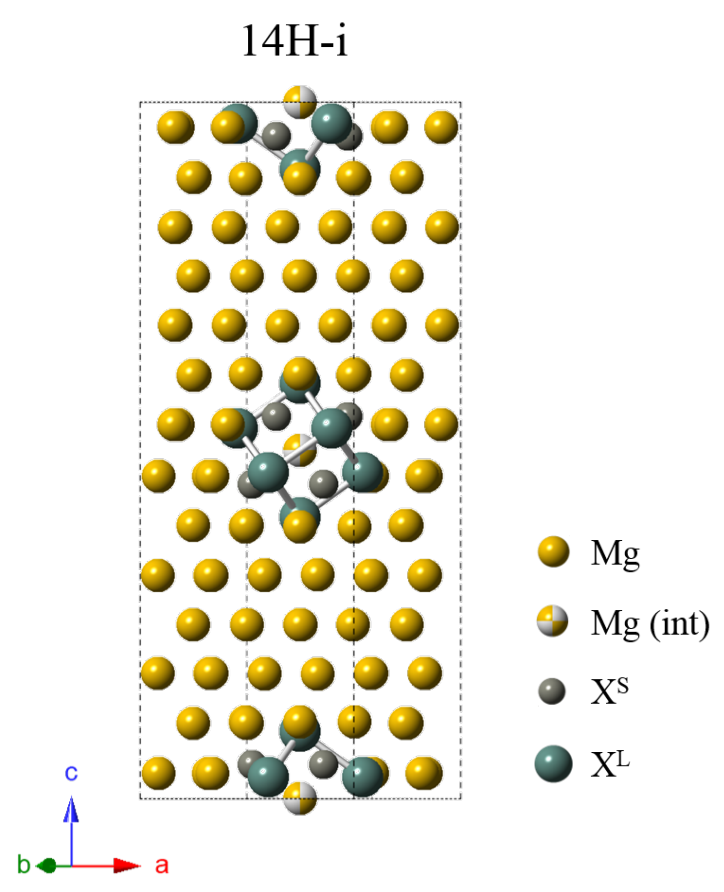

Figure 1: The $\mathrm{Mg}_{71} \mathrm{X}_{8}^{\mathrm{L}} \mathrm{X}_{6}^{\mathrm{S}} 14 \mathrm{H}-\mathrm{i}$ LPSO crystal structure. A full $\mathrm{X}_{6}^{\mathrm{S}} \mathrm{X}_{8}^{\mathrm{L}} \quad \mathrm{L}_{2^{-}}$ arranged cluster can be seen in the middle of the cell with a $\mathrm{Mg}$ interstitial site at the center. Note that the origin has been shifted by $0.5,0.5,0$ with respect to coordinates in Table 1. 


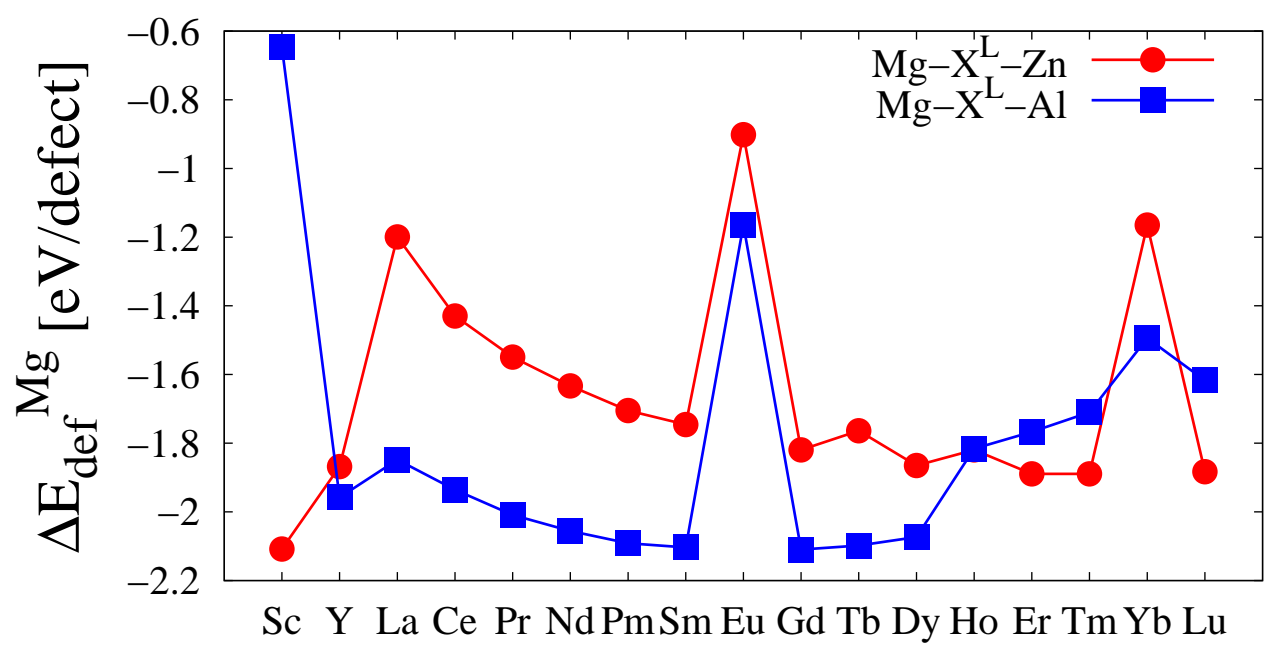

Figure 2: DFT predicted $\mathrm{Mg}$ interstitial defect formation energy, $\Delta \mathrm{E}_{\text {int }}^{\mathrm{Mg}}$, for the gradual $14 \mathrm{H}$ LPSO structures (Equation 4). Negative values indicate the interstitial $\mathrm{Mg}$ atom promotes the stability of the LPSO structures. 


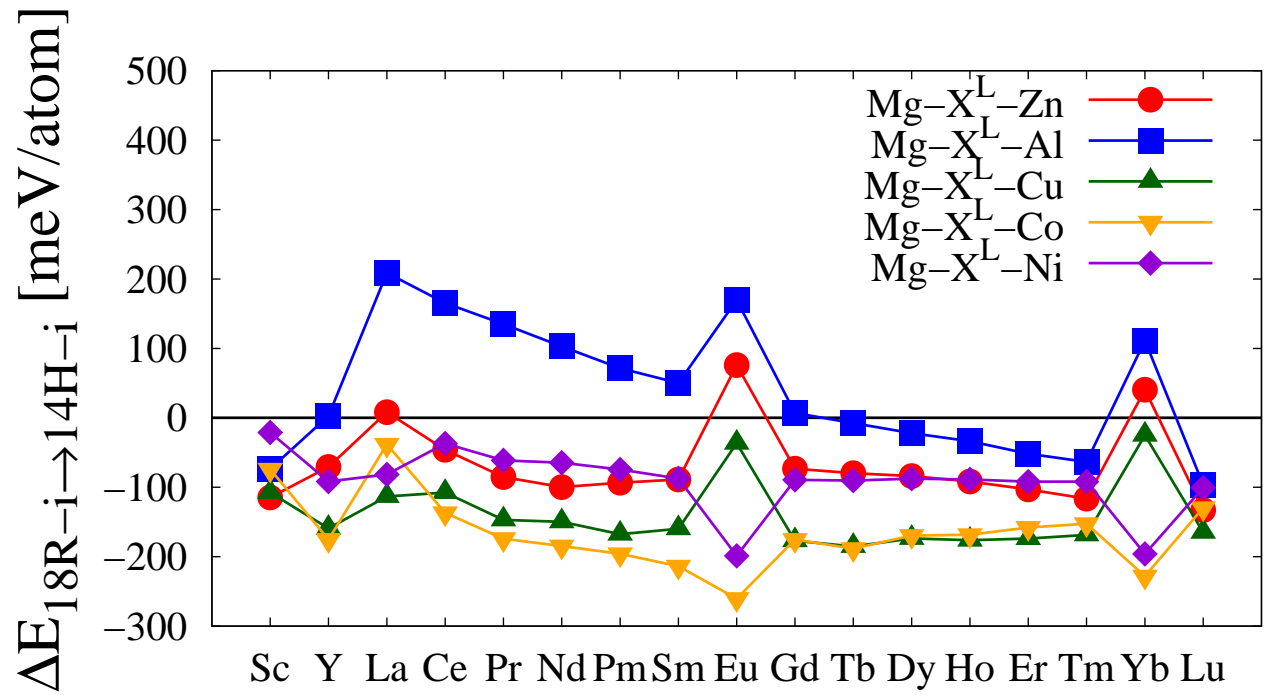

Figure 3: DFT predicted energy for the transformation between the 18R-i and $14 \mathrm{H}-\mathrm{i}$ LPSO structures (Equation 8), $\Delta E_{18 \mathrm{R}-\mathrm{i} \rightarrow 14 \mathrm{H}-\mathrm{i}}$. Negative values indicate the $14 \mathrm{H}-\mathrm{i}$ structure is energetically preferred over $18 \mathrm{R}-\mathrm{i}$. 


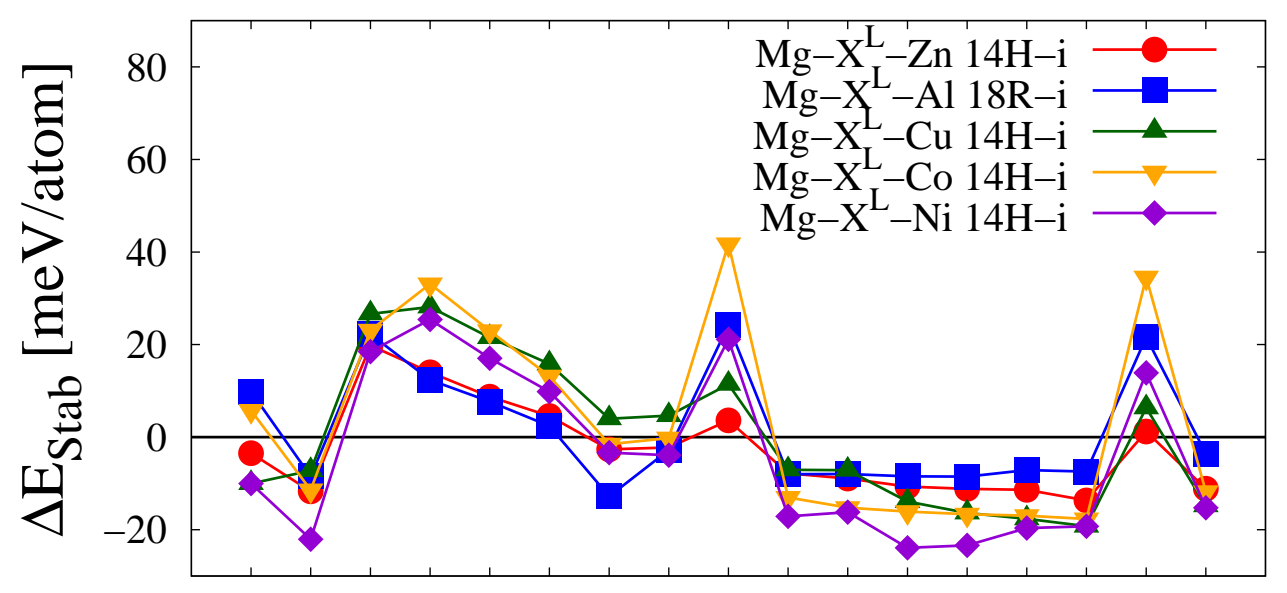

Sc Y La Ce Pr NdPmSm Eu Gd Tb Dy Ho Er Tm Yb Lu

Figure 4: DFT predicted relative stability of the indicated LPSO structure with respect to the lowest energy combination of all phases known from the ICSD and prototypes database in their respective ternary systems, $\Delta \mathrm{E}_{\text {stab. Negative }}$ values indicate the LPSO structure is thermodynamically stable. The sets of stable phases at the LPSO compositions can be found in Tables 8-12. 


\section{Ternary $\mathrm{Mg}-\mathrm{X}_{\mathrm{L}}-\mathrm{X}_{\mathrm{S}}$ LPSO Stability}
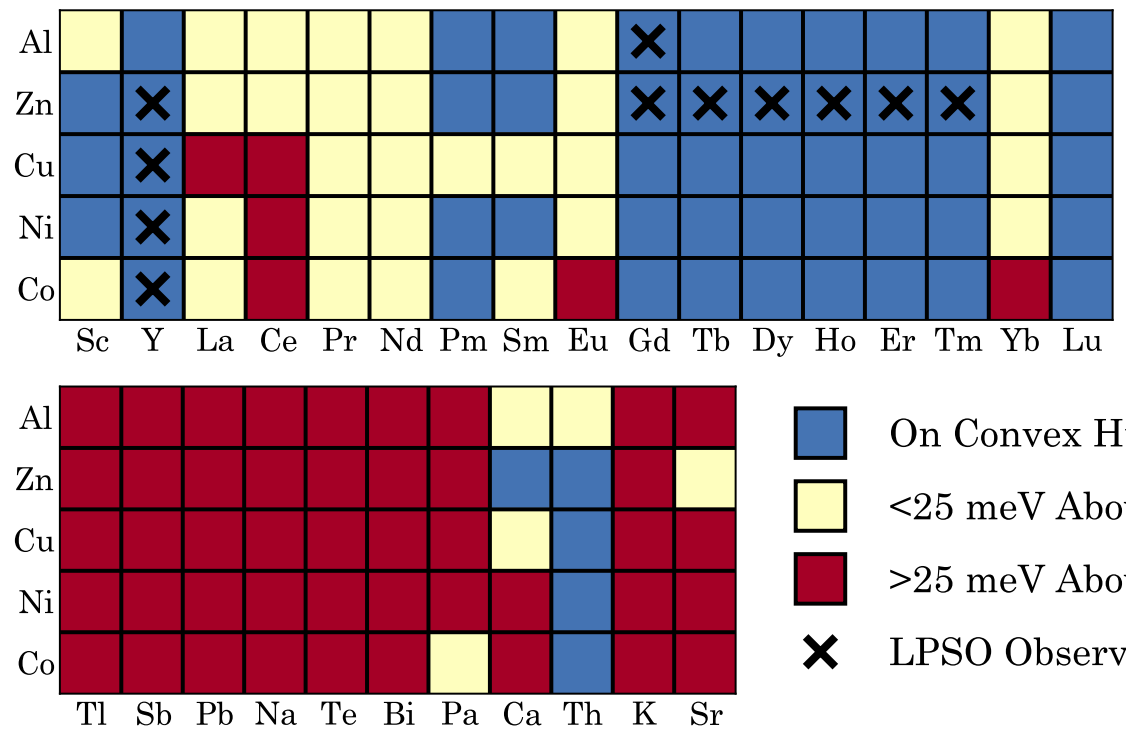

$\square$ On Convex Hull (CH)

$\square<25 \mathrm{meV}$ Above $\mathrm{CH}$

$\square>25 \mathrm{meV}$ Above $\mathrm{CH}$

X LPSO Observed

Figure 5: DFT predicted stability of $14 \mathrm{H}-\mathrm{i}$ and 18R-i LPSO structures for all $\mathrm{Mg}-\mathrm{X}^{\mathrm{L}}-\mathrm{X}^{\mathrm{S}}$ ternary systems explored in this work. $\mathrm{X}^{\mathrm{S}}$ and $\mathrm{X}^{\mathrm{L}}$ elements are given along the vertical and horizontal axes, respectively. Color coding is defined by the values of $\Delta \mathrm{E}_{\text {stab }}$ given in Tables 8-12: blue for on the convex hull $\left(\Delta \mathrm{E}_{\text {stab }}<\right.$ $0)$, yellow for near the convex hull $\left(0<\Delta \mathrm{E}_{\text {stab }}<25 \mathrm{meV} /\right.$ atom $)$, and red for far from the convex hull $\left(25 \mathrm{meV} /\right.$ atom $\left.<\Delta \mathrm{E}_{\text {stab }}\right) . \mathrm{X}^{\mathrm{L}}=\mathrm{RE}$ systems are given at top and $\mathrm{X}^{\mathrm{L}} \neq \mathrm{RE}$ systems at bottom. Experimentally observed LPSO-forming systems are also indicated[3-13]. Note that blue squares without an " $\mathrm{x}$ " indicate systems where we predict as-yet-unobserved LPSO phases to be stable. 


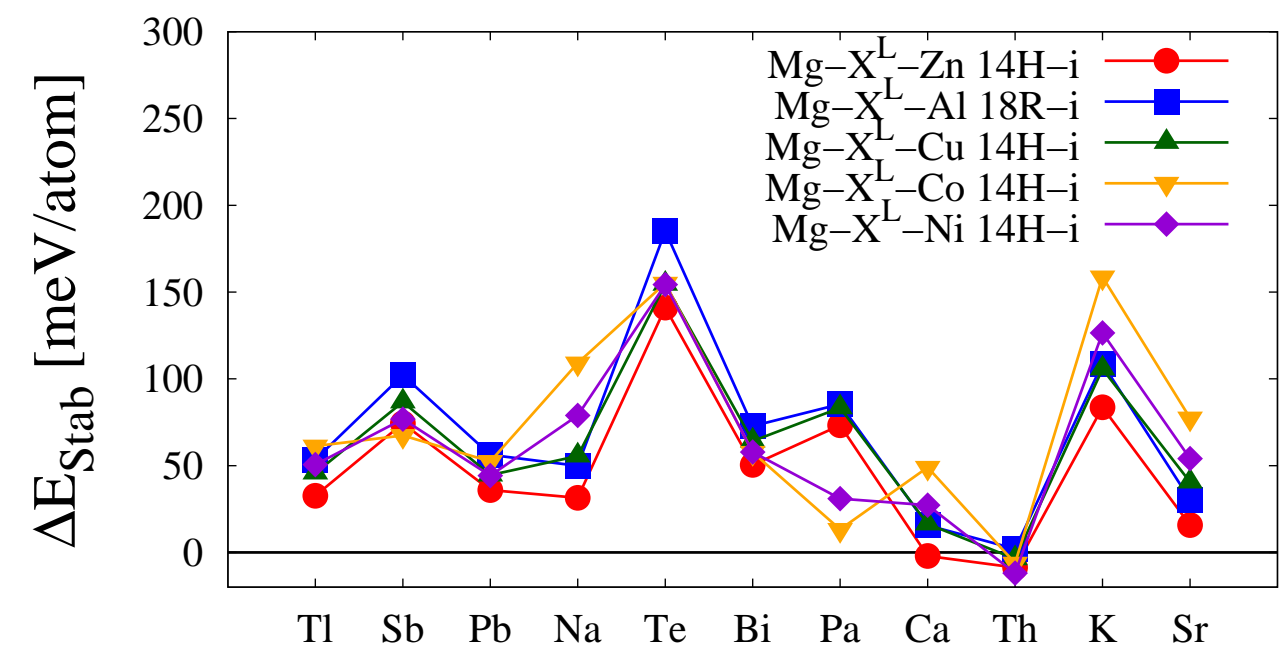

Figure 6: DFT predicted relative stability of the indicated LPSO structure with respect to the lowest energy combination of all phases known from the ICSD and prototypes database in their respective ternary systems, $\Delta \mathrm{E}_{\text {stab }}$. Negative values indicate the LPSO structure is thermodynamically stable. The sets of stable phases at the LPSO compositions can be found in Tables 8-12. Elements are ordered in increasing impurity volume in $\mathrm{Mg}$. 

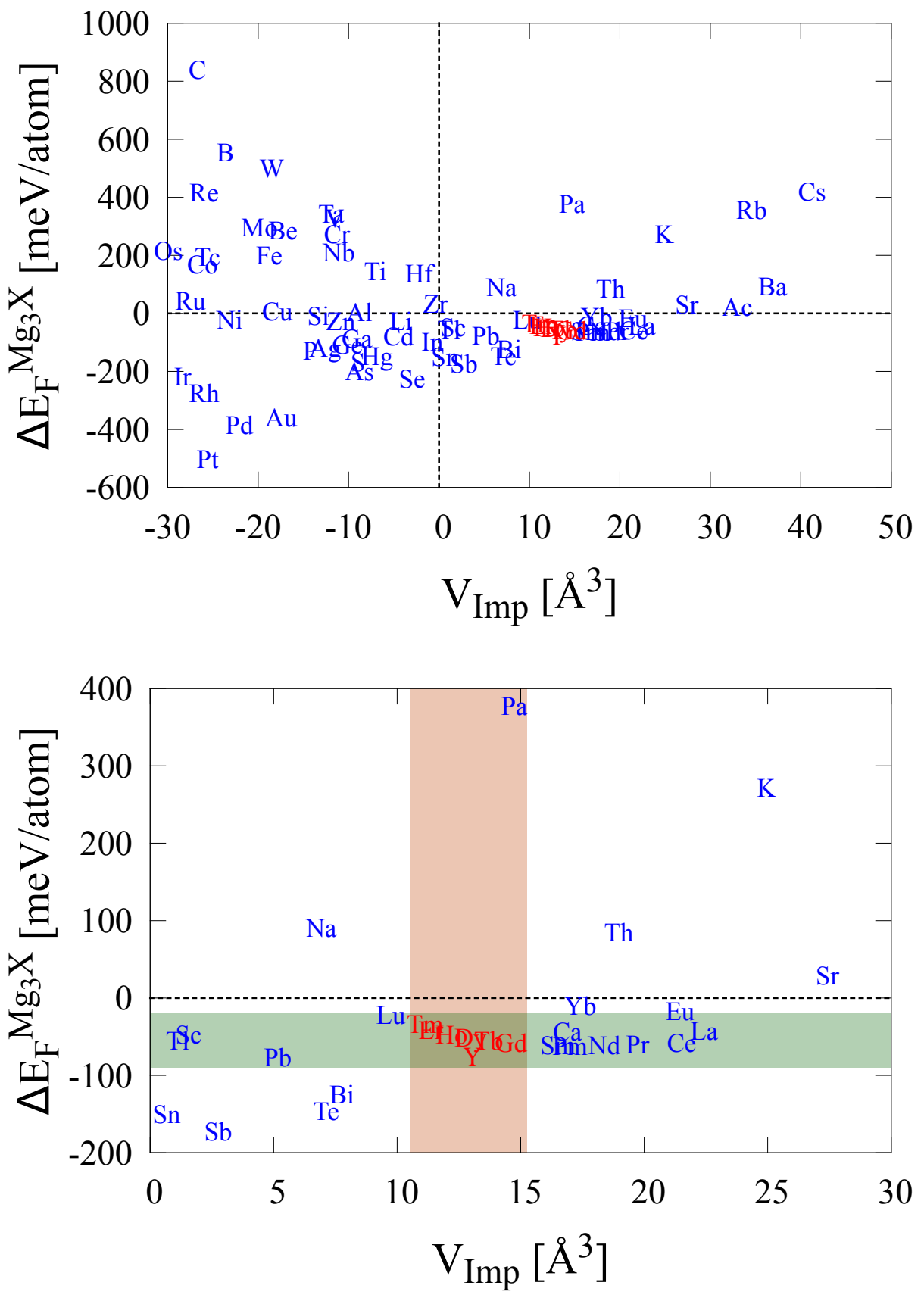

Figure 7: Formation energy of $\mathrm{Mg}_{3} \mathrm{X} \mathrm{L1} 1_{2}$ vs. the impurity volume of $\mathrm{X}$ in $\mathrm{Mg}$ (top) for all elements tested in this work and (bottom) close up of positive impurity volume region. Observed LPSO-forming $\mathrm{X}^{\mathrm{L}}$ elements are in red font. Shaded regions correspond to range of formation energies and impurity volumes for observed LPSO-forming $\mathrm{X}^{\mathrm{L}}$ elements. 